\title{
Upland lakes of the Carajás region: origin and development through time
}

José Tasso Felix Guimarães ${ }^{a^{*}}$, Prafulla Kumar Sahoo ${ }^{\mathrm{a}}$, Pedro Walfir Martins SouzaFilho $^{a}$, Marcio Sousa da Silva ${ }^{\mathrm{a}}$, Tarcísio Magevski Rodrigues ${ }^{\mathrm{b}}$, Edilson Freitas da Silva $^{c}$, Luiza Santos Reis ${ }^{\mathrm{d}}$, Mariana Maha Jana Costa de Figueiredo ${ }^{\mathrm{a}}$, Karen Lopes da Silva $^{a}$, Wilson Filgueira Batista Junior ${ }^{\mathrm{a}}$, Wilson Nascimento Júnior ${ }^{\mathrm{a}}$, Aline Mamede Moraes $^{\mathrm{a}}$, Alessandro Sabá Leite ${ }^{\mathrm{a}}$, Renato Oliveira Silva Júnior ${ }^{\mathrm{a}}$, Léa Maria Medeiros Carreirac $^{\mathrm{c}}$, Vladimir Eliodoro Costa ${ }^{\mathrm{e}}$, Roberto Dall'Agnol ${ }^{\mathrm{a}}$

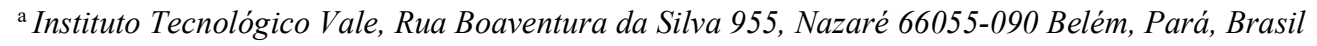

${ }^{\mathrm{b}}$ Gerência de Meio Ambiente-Minas de Carajás, Departamento de Ferrosos Norte, Estrada Raymundo Mascarenhas, S/N Mina de N4, 68516-000, Parauapebas, Pará, Brazil

${ }^{\mathrm{c}}$ Museu Paraense Emílio Goeldi, Coordenação de Botânica, Av. Perimetral 1901, Terra Firme 66077830. Belém, Pará, Brasil

${ }^{\mathrm{d}}$ Centro de Energia Nuclear na Agricultura, Laboratório C-14, Av. Centenário, 303, São Dimas, 13400970, Piracicaba, São Paulo, Brazil

e Centro de Isótopos Estáveis, Instituto de Biociencias, Universidade Estadual Paulista, Distrito de Rubião Junior s/n, 18618-970, Botucatu-SP, Brazil.

* Corresponding author. Instituto Tecnológico Vale, Rua Boaventura da Silva 955, Nazaré 66055-090 Belém, Pará, Brasil.

E-mail adresses: tasso.guimaraes@itv.org (J.T.F. Guimarães).

\begin{abstract}
Upland lakes (ULs) of the Carajás, southeastern Amazonia, have been intensively studied to their evolution during the Quaternary, as well as the development of the associated biota. In this review, several classical and modern approaches from structural geology to the pollen rain and sedimentary data which cover an area of around 41,300 $\mathrm{km}^{2}$ were compiled. Multi-elemental geochemistry indicates that the detrital sediments derived from weathered crusts and soils, while the sedimentary organic matter represent autochthonous (siliceous sponge spicules, algae, macrophytes) and allochthonous (C3 plants and freshwater DOC) sources. Modern pollen rain suggests that even small lakes and canga areas can reflect forest signal, which depends on the topographic control and prevailing wind direction on pollen deposition. Integrated data of the sedimentary cores indicate that the active lakes never dried up during the last $50 \mathrm{ka}$ cal BP. However, subaerial exposure occurs on filled lakes such as ST02 Lake during the LGM, LB3 and R2 lakes at the mid-Holocene due to drier paleoclimate conditions. Considering the organic proxies, only LB3 Lake presents expansion of C4 canga (montane savanna) plants since ULs of the Serra da Bocaína does not present siderites. Siderite formation on ULs deposits also points to drier paleoenviromental conditions, interrupting predominantly wet conditions. However, there is no evidence for widespread expansion of savanna into Southeastern Amazonia during the late Pleistocene and Holocene.
\end{abstract}

Keywords: Amazonia, Upland lakes, Serra dos Carajás, Palaeoenvironmental reconstruction, Quaternary, Geology 


\section{Highlights}

- Carajás lakes represents singular ecosystems in Amazon uplands;

- The lakes were formed by structural and dissolution processes during the late Cenozoic;

- Water quality and sedimentary processes are controlled by lake catchment characteristics;

- Multi-proxy approach is more robust (or reliable) for paleoenvironmental reconstructions

\section{Introduction}

Upland lakes (ULs) in the Brazilian Amazon are singular mid-altitude landforms (from $400 \mathrm{~m}$ to $800 \mathrm{~m}$ ) formed over iron and iron-aluminous lateritic crusts as a result of successive structural processes, weathering (chemical, physical and biological) and erosion cycles under tropical climate conditions (Vasconcelos et al., 1994; Costa et al., 2005; Maurity and Kotschoubey, 1995). These lakes are hydrologically restricted and constitute depositional environments with variable accommodation space for sediment deposition, and accordingly they are classified as active and inactive lake systems, with the latter representing upland swamps (Reis et al., 2017).

The ULs sediments are highly influenced by natural and local characteristics of each catchment basins, including parent rock properties, source-area weathering, rheology, morphology and vegetation cover, as well as the primary productivity of the central basins (Sahoo et al., 2015, 2016a, 2017a). The interrelation of these factors have controlled the geochemical and limnological characteristics of these lakes through time (Sahoo et al., 2017b). In general, ULs present thick Quaternary deposits with relatively continuous records of paleoenvironmental changes, as such observed in the Morro dos Seis Lagos (northwestern Amazonia), Serras de Maicuru and Maraconaí (northestern Amazonia), and dos Carajás (southeastern Amazonia) (Colinvaux et al., 2001; Bush et al., 2004; Sifeddine et al., 2001; Guimarães et al., 2016; Reis et al., 2017).

The western and eastern ULs have provided exceptional records for paleoclimate and paleovegetation modelling, allowing to evaluate the effects of the last glacial and interglacial periods on lakes and vegetation patterns (Colinvaux et al., 2001; Bush et al., 2004; Sifeddine et al., 2001; Reis et al., 2017). In addition, they serve as excellent database for discussions about speciation events throughout the Amazonia (Arruda et al., 2018), However, mismatches between paleoclimate data of western and eastern Amazonia are still recurrent (Reis et al., 2017; Guimarães et al., 2017, 2018a, b), which causes difficulty in analysis and interpretation of past and current vegetation distribution on large spatial scales. For instance, speleothems records suggested that eastern Amazonia was wetter during the mid-Holocene than present (Wang et al., 2017). It contradicts palynological and geochemical data from Serra dos Carajás. Such studies proposed extensive dries up of the upland lakes and dominance of montane savanna (canga vegetation) and dry-adapted semideciduous tropical dry forests (SDF), in detriment of humid evergreen tropical forest (HETF) (Absy et al., 1991; Sifeddine et al., 2001; Hermanowski et al., 2014; Reis et al., 2017; Guimarães et al., 2016, 2018b).

Even the drainage basins of the ULs of Amazonia developed on basement lateritic crusts may locally present a great variety of lithotypes, geomorphological settings, and consequently, structural and floristic composition of plant communities (Nunes et al., 2015). The complexity of this system is also responsible for the development of 
different microhabitats in the crusts, with high beta diversity and endemism of plant species (Guimarães et al., 2014; Nunes et al., 2015; Viana et al. 2016).

Palynological and geochemical studies were conducted on upland swamps in this region (Absy et al., 1991; Sifeddine et al., 2001; Cordeiro et al., 2008; Hermanowski et al., 2014; Reis et al., 2017; Guimarães et al., 2016, 2018b), so most of these records may reflect hydrarch succession and basin-filling rather than a paleoclimate signal. ULs may become more similar to terrestrial habitats during negative water balance produced by prolonged hydric stress, which may affect ecological attributes of water-dependent biota (Lopes et al., 2011; Mormul et al., 2015). On the other hand, ULs that remained relatively resilient to these environmental conditions may act as microrefuges for such organisms. Thus, both physical and biological aspects, as well as their dynamic nature, must be carefully evaluated over shorter (annual to decadal) and longer (century to millennial) time scales through an integrated approach using surface or subsurface records from geological, geomorphological, sedimentological, geochemical, limnological, botanical and paleontological prospecting. This is highly recommended for a precise environmental assessment and regional correlation of events, which should be the foundation of any paleoenvironmental reconstruction, since ULs may respond differently under similar paleoclimate change (Guimarães et al., 2018a). In this scenario, this study presents multi-proxy characterizations of the surface and subsurface processes and landforms of ULs, as well as new data and proxies about late Quaternary environmental dynamic of the Carajás region, southeastern Amazonia.

\subsection{Regional geological setting}

The study site is located in the eastern portion of the Carajás Domain, northeast portion of the Carajás Mineral Province, southeastern Amazonia (Fig. 1), which is an important metallogenic province on a global scale (Tolbert et al., 1971). This province is represented by felsic and mafic granulites (Pium Complex), granodioritic and tonalites (Xingu Complex), which form the Meso-archean basement, and by supracrustals Neo-archean metavolcanic-sedimentary sequences and banded iron formations (BIFs) related to Greenstone Belts of the Itacaiúnas Supergroup (Barros et al. 2010; Costa, 2007; Macambira 2003; Rosière et al. 2005). Sedimentary successions of the Águas Claras Formation were deposited over the Greenstone Belts (Nogueira et al., 1995).

The weathering of the Itacaiúnas Supergroup due to the tropical paleoclimate conditions of the Cenozoic allowed the development of extensively Fe-Al lateritic crusts from BIFs and metavolcanic rocks (Maurity and Kotschoubey, 1995; Vasconcelos, 1999). The formed crusts underwent a progressive degradation caused by paleoclimate changes, regional uplifting and lowering of the groundwater base levels. Therefore, the weathering reached deeper portions, while intense pseudo-pisolitization occurred in the upper part of the crust. Highly porous and permeable zones developed near the contact with the saprolite horizon due to the mobilization of $\mathrm{Si}, \mathrm{Fe}$ and $\mathrm{Al}$, and lateral fluxes of underground waters following structural and dissolution features. Subsequently, ULs with caves in their borders were formed according to the evolution of these zones and collapse of the overlying crust (Maurity and Kotschoubey, 1995). ULs only occur in the upper lateritic terrains (plateaus) of the Carajás region at 600 to $760 \mathrm{~m}$ altitude, such as Serra dos Carajás (S11 and Norte), do Tarzan, da Bocaína and Leste (Fig. 1). 


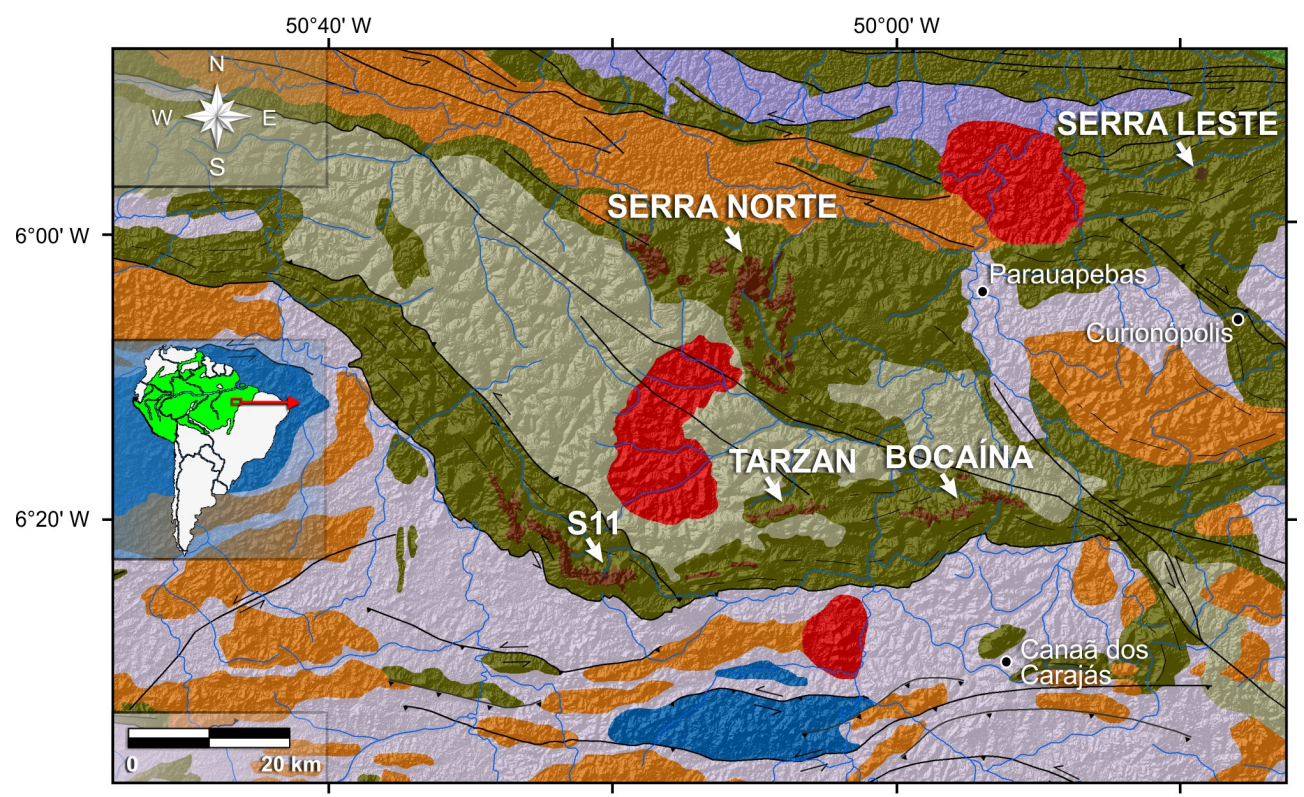

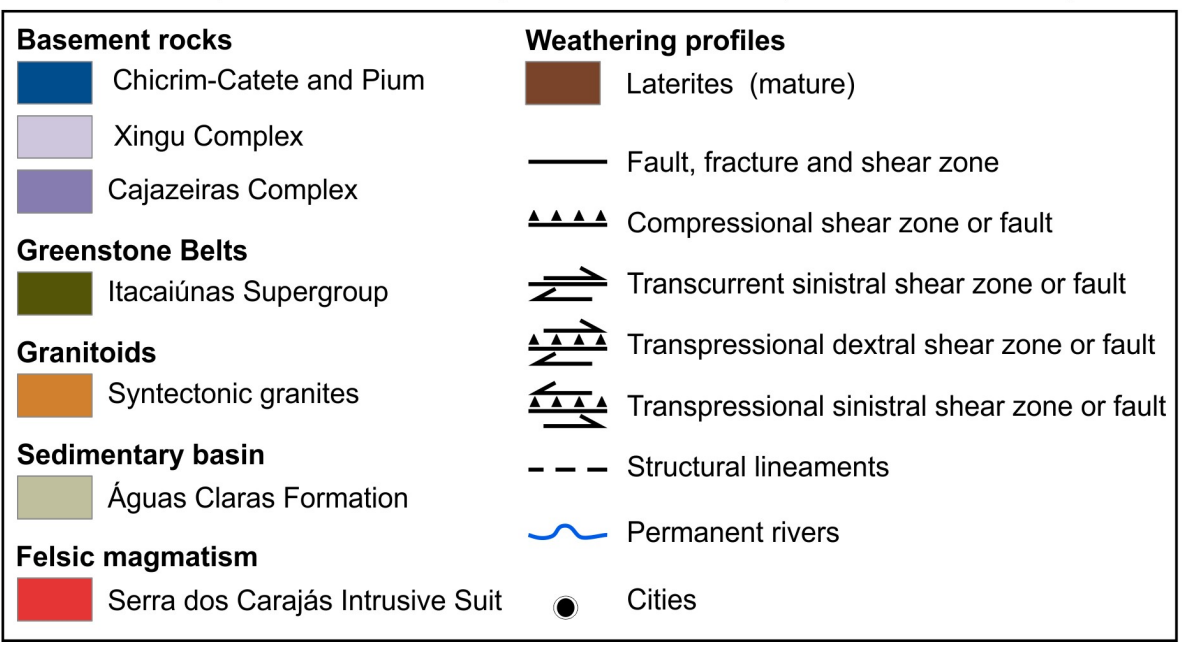

Fig. 1. Geological map showing the main lithological units of the Carajás region in the Brazilian Amazon. The studied lakes are located in the lateritic crusts of the Serra dos Carajás (S11 and Norte), do Tarzan, da Bocaína and Leste.

Considering the influence of structural features in the formation of ULs, the lateritic crusts of the Serra Sul dos Carajás are cut and displaced by sets of E-W, N-S to NE-SW sinistral normal oblique faults. ULs, such as Violão Lake (S11), are strongly controlled by these sets of fractures and their related folds, both in position and shape. Most of these fractures and faults were reactivated as collapse normal faults and occur along the borders of the lake, with a step-down displacement towards its central basin (SouzaFilho et al., submitted). Partial dissolution of the lateritic crust by the run-off and deposition of clastic sediments are in agreement with the major scale lake development (Souza-Filho et al., 2016a).

Based on shallow seismic surveys and sediment cores, it was possible to identify the geometry of sedimentary units deposited in the ULs of the Carajás region (Souza-Filho et al., 2016a). The lake basement is represented by well-defined reflection with no penetration due to total acoustic reflection at the lateritic crust leading to strong 
amplitude lake-bottom multiples. The basal deposits correspond to basinward prograding clinoforms associated with delta fans located near the main drainage inflows. Underflow processes are responsible for carrying fine-grained particles towards the lake depocenter interrupted by siderite beds. The upper deposits are related to massive or structureless mud with some scattered peat fragments. This facies arrangement produces fining and thinning upward cycles. However, cycle thickness may vary if accommodation space is high enough to produce high deposition angles, such those observed on active ULs.

\subsection{Regional physiography and climate}

The studied ULs are situated in the plateaus of the Serra dos Carajás (Sul and Norte), do Tarzan, da Bocaína and Leste (Fig. 1), inserted into the Itacaiúnas River Watershed (IRW) that drains an area of around $41,300 \mathrm{~km}^{2}$ (Souza Filho et al., 2016b). These lakes are active or inactive (filled) depending on the sedimentary filling stage (Guimarães et al., 2017). Considering the main vegetation types, HETF colonize the slopes of the plateaus and are associated with metavolcanic rocks of the Itacaiúnas Supergroup. SDF may be observed over fragile zones of detritic crust and mafic sills in the plateaus. Montane savanna (canga vegetation) occupies the largest areas over lateritic crusts, and it is mainly related to edaphic conditions (Skirycz et al., 2014).

The rainfall regime is characterized by two well-defined seasons, one rainy, regionally known as Amazonian winter, and another dry, which is called Amazonian summer (Lopes et al., 2013). The rainy (November to May) and dry (June to October) seasons are well defined, in which total annual rainfall can vary from 1,545 $\mathrm{mm}$ to $1,863 \mathrm{~mm}$ during the rainy season and from $159 \mathrm{~mm}$ to $321 \mathrm{~mm}$ during the dry season (Silva Júnior et al., 2017). The main weather system that affects the rainfall regime during the rainy season in southeastern Pará, in the Itacaiúnas River Watershed region, is the band of convective clouds of the Intertropical Convergence Zone (ITCZ). In the dry season, the rainfall regime is influenced by frontal systems, which are responsible for the convective activity over the eastern Amazon (De Souza et al., 2017). Specifically in the IRW region, the mean value recorded is $27.2^{\circ} \mathrm{C}$, with a minimum annual temperature of $26.6^{\circ} \mathrm{C}$ in January and a maximum annual temperature of $28.1^{\circ} \mathrm{C}$ in September (Tavares et al., 2018).

\section{Research methods}

For morphological mapping of the lake basins, worldview-2 multispectral satellite imagery with $2 \mathrm{~m}$ resolution and LiDAR (Light Detection and Ranging) data were integrated to produce a digital elevation model (DEM). The images were orthorectified and the resulting digital values were converted to terrain reflectance by the ATCOR algorithm using PCI Geomatica 13. This dataset was used for interpretation of the morphological features and real-time navigation during field surveys, which were supported by a Differential Global Positioning System. The main lithotypes and soil samples were described and collected according to Maurity and Kotschoubey (1995) and Sahoo et al. (2017a).

Bathymetric data and seismic profiling were conducted in the active lakes using a $200 \mathrm{kHz}$ Raytheon DE719E and StrataBox ${ }^{\mathrm{TM}}$ SyQuest Echo Sounders, respectively. The bathymetric maps and digital terrain model were designed for planimetric map with $1 \mathrm{~m}$ isobaths of interval and $3 \mathrm{D}$ view to allow a precise visualization of the lake morphology according to Silva et al. (2018). Based on these maps, 145 surficial $(0-10 \mathrm{~cm})$ sediment 
samples were collected using a Van Veen Grab sampler. In addition, eleven sediment cores were collected using a Livingstone-type drive rod piston corer (operated over an adapted AIRE Leopard Cataraft) and a Russian peat borer on active and filled lakes, respectively (Table A.1; Figure A.1). Surface and core samples were described according to the classification system of lacustrine sediments of the Global Lake Drilling Program (Schnurrenberger et al., 2003) and facies analysis (Walker, 1992).

Major and minor elements in sediments, soils and crusts were determined in pulverized samples by inductively coupled plasma optical emission spectrometry (ICPOES) and X-ray fluorescence spectrometry (XRF), while trace elements by inductively coupled plasma optical mass spectrometry (ICP-MS). Data accuracy analysis and statistical treatment were carried out according to Sahoo et al. (2019).

The main vegetation types were defined during field observation and DEM interpretation. See Guimarães et al. (2016) for detailed information about the methodological approach for vegetation survey and palynological analysis of the study site. Fertile material was incorporate in our pollen database (PALIITV). Thus, it helps to calibrate all pollen data of this work. In addition, artificial pollen traps (Gosling et al., 2003) installed along the drainage basin of the LTM2 Lake allowed the evaluation of the annual pollen signal of very small canga areas surrounded by HETF and SDF.

For $\delta^{13} \mathrm{C}$ and $\delta^{15} \mathrm{~N}$ analysis, sediment samples were determined by an elemental analyzer coupled to a Continuous Flow Isotopic Ratio Mass Spectrometer (CFIRMS). Total sulphur (TS) and total organic carbon (TOC) were measured using a LECO CS300 combustion analyzer. See Sahoo et al. (2017a) for more details about sample preparation and data treatment.

Around $1 \mathrm{~cm}^{3}$ of sediment was collected in the surficial and core (at intervals of around 2.5 to $5 \mathrm{~m}$ depth) samples for palynological analysis, which was based on classical techniques for palynomorphs extraction including acetolysis (Faegri and Iversen, 1989). Identification were conducted following Guimarães et al. (2018a).

One hundred twenty-four bulk samples of about 1-2 g each were collected for radiocarbon dating (Table A.2), which was performed by an Accelerator Mass Spectrometry (AMS). The age-depth model was made based on Bayesian accumulation (Bacon) histories for lake and peat deposits (Guimarães et al., 2016; Reis et al., 2017; Blaauw and Christen, 2011), using $\mathrm{R}$ as an interface and Intcal13.14c calibration dataset (Reimer et al., 2013).

For limnological study, water samples were collected (surface, middle and bottom of the lake) in both rainy and dry seasons between 2013 and 2016 using Van Dorn water sampler. Sample collection and analysis of various inorganic, organic and bacteriological parameters were carried out by using Bureau Veritas analytical facilities following referred guidelines (EPA 2004; SMEWW 2005; and CETESB 2006). In-site measurement of physico-chemical parameters were carried out using Horiba W-20XD multi sensor probe.

\section{Surface geology and geobotany of the catchment basins}

The lateritic crusts of the study area have distinct mineralogical assemblages and structural features, rheology and geomorphology, which rule its outcropping. Thus, they may be genetically classified as structured (iron-ore), detrital and Al-rich crusts (Fig. 2).

Structured and detrital crusts were formed by the lateritization of BIFs, and contain hematite, magnetite, goethite and secondarily, quartz and clay minerals. These crusts are generally thick and more resistant to modern weathering, and then, not suitable to soil formation, or forming only Petric Plinthosols (Nunes et al., 2015). In addition, they are 
predominant on higher topographical quotas of the study site. On the other hand, crusts formed by the lateritization of mafic rocks (Al-rich crusts) have more clay minerals, as well as gibbsite, especially close to the saprolite horizon. They are less resistant to weathering, and occur on lower quotas than structured and detrital crusts. Thus, these crusts may produce thicker soils (i.e. Ferrasols).
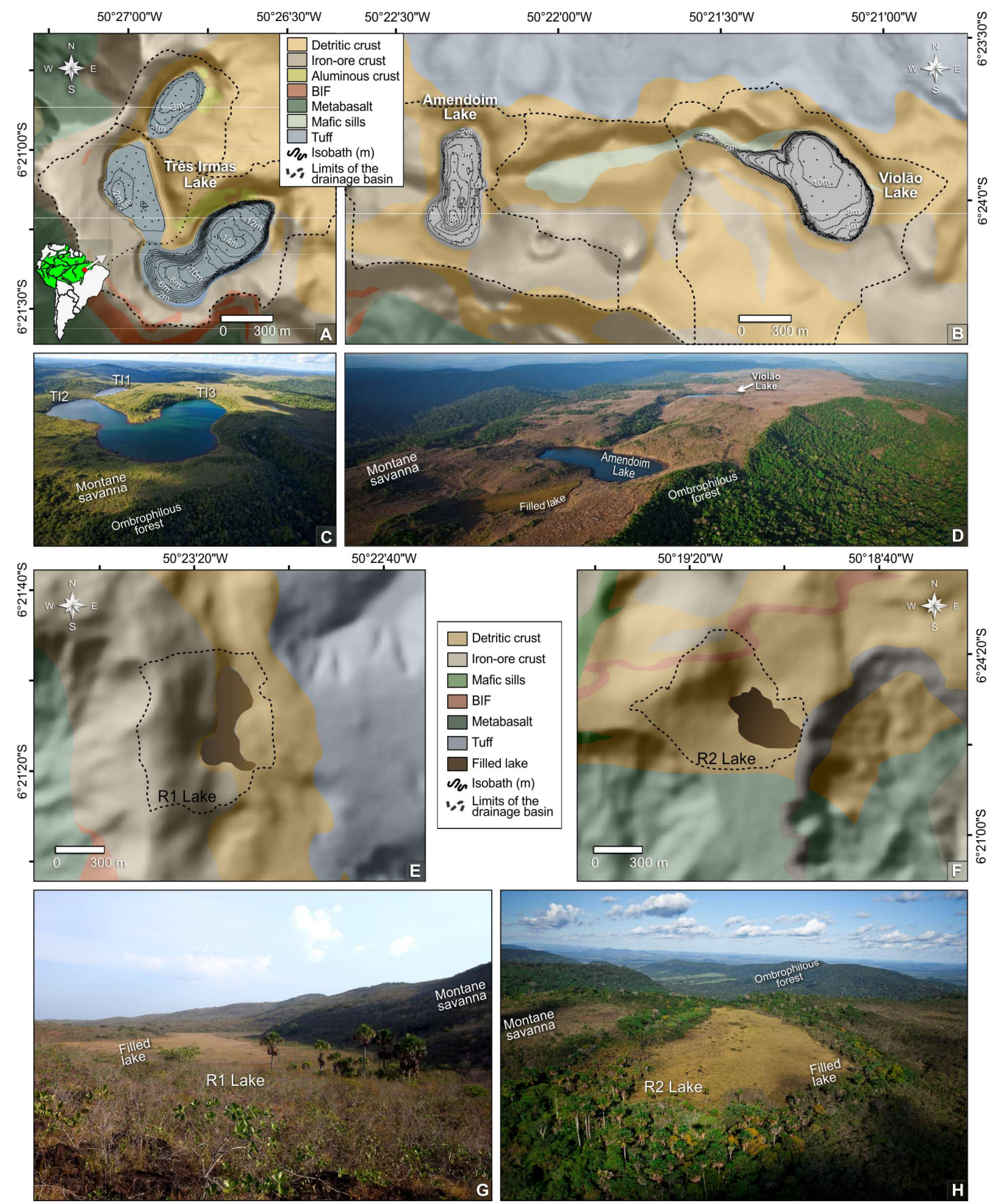

Fig. 2. A-B) Digital elevation model (DEM) integrated with bathymetric data showing western and eastern portion of the Serra Sul Plateau showing the main lithotypes described in the catchment basins of active ULs. Aerial photograph of the C) Três Irmãs, D) Amendoim and Violão Lake. E-F) DEM showing the main lithotypes described in the catchment basins of filled ULs. G-H) Aerial photograph of the filled ULs. 
The variability of lateritic crusts and resulting soils may rule the distribution of modern vegetation due to shallow, patchy and acidic soils with low water-retention and nutrient availability, high insolation and temperature (Skirycz et al., 2014; Schaefer et al., 2016). Therefore, the extensive cover of detrital and structured crusts allowed the widespread development of canga vegetation and hindered the colonization of tree species (Fig, 4a-d), such as SDF and HETF (Skirycz et al., 2014; Guimarães et al., 2014; Nunes et al., 2015). This is supported by the elevated foliar $\delta^{13} \mathrm{C}$ values observed in Amazon cangas than in neotropical forests, which indicate a more pronounced water shortage in cangas than in forests (Mitre et al., 2018). SDF only occur over structural features and distinct rheological settings of the detrital and structured crusts, while HETF is restricted to soils over Al-rich crusts and mafic sills. The latter is predominant in the slopes of the of the Serra dos Carajás, and locally, on lake borders of the Três Irmãs and Violão lakes (Fig. 2a-d). Palms and macrophytes extensively occur on filled lakes (Fig. 2e-h). The dominant plant species of each physiognomy are described on Table 1.

\section{Modern sedimentation patterns: Basin morphology and source-to-sink relationship}

Lakes sediments are archives of various proxies that help to understand the local and regional climate. However, the profound interpretation of proxy data derived from lake sediment records requires an in-depth knowledge of the lake-specific modern sedimentological processes and their controlling factors such as rate of weathering, catchment materials and basin morphology (Viehberg et al., 2012; Wenrich et al., 2013; Hasberg et al., 2018). This helps to close the gaps in the knowledge on source-sink interactions through time.

This is particularly interesting for Amazonian ULs, which are located in the Carajás mineral province, as these lakes are best fit for paleoclimate studies (Guimarães et al., 2016, 2017). The active ULs of the Carajás region have mid-altitude ranges (695-725 $\mathrm{m})$, very small surface areas $\left(<0.5 \mathrm{~km}^{2}\right)$, shallow to very shallow depths $(<10 \mathrm{~m}$ : mean depth), and catchments with relatively high declivities $\left(>20^{\circ}\right.$ and maximum of $\sim 60^{\circ}$ ) (Silva et al., 2018). Violão and Amendoim lakes are separated by an intermediate basin that prevents any surface connection of water among them (Fig. 2b). The catchment of Amendoim Lake was composed by two active lakes (Fig. 2d), but the smaller one located in the western portion was progressively filled by detritic and organic sediments, and nowadays represents a swamp colonized by macrophytes (Guimarães et al., 2017). Once the three lakes of Três Irmãs are connected, the water flow follows the elevation gradient from TI1 to TI3 (Fig. 2c), forming a small waterfall between them (Silva et al., 2018).

The multi-proxy geochemical analyses of surface sediments of these lakes, soils and lithotypes of their catchments, supplemented by statistical methods, evaluated the major factors such as catchment lithology, source area weathering, transport, and depositional processes that influencing the modern sedimentation in the lakes (Sahoo et al., 2015, 2016a, 2017a, 2019). The results show that detritic sediments are mainly enrichment of $\mathrm{Fe}_{2} \mathrm{O}_{3}$ and $\mathrm{P}_{2} \mathrm{O}_{5}$ and $\mathrm{Se}$ when compared to upper continental crust (UCC). High Chemical Index of Alteration (CIA), Mafic Index of Alteration (MIA) and Index of Laterization (IOL) values indicate intense chemical weathering at source areas, however, similar values between soils and catchment rocks indicates the weathering transformation between them and its erosion led to its deposition as sediment into the lakes (Sahoo et al., 2017a). 
PCA analysis shows 5 major groups of geochemical association (Fig. 3a), with the major detritic groups being similar to catchment basin laterites (Sahoo et al., in 2019). The Ti-Zr-Hf-Y-Nb-HREEs (Gp-1) corresponds to resistant minerals, which possibly remained stable during lateritization, while different behavior of LREEs (Gp-2) relative to HREE indicates their relative mobility during laterite formation and reprecipitation by REE bearing minerals. The Al-Sc-V-Cr association (Gp-3) in sediments reflects the signature of country rock, such as metavolcanic components. TOC-SO3-Hg-Se (Gp-4) is controlled by organic matter, while Fe-P-Mo-As-Zn (Gp-5) in sediments is influenced by Fe-oxyhydroxide precipitation.
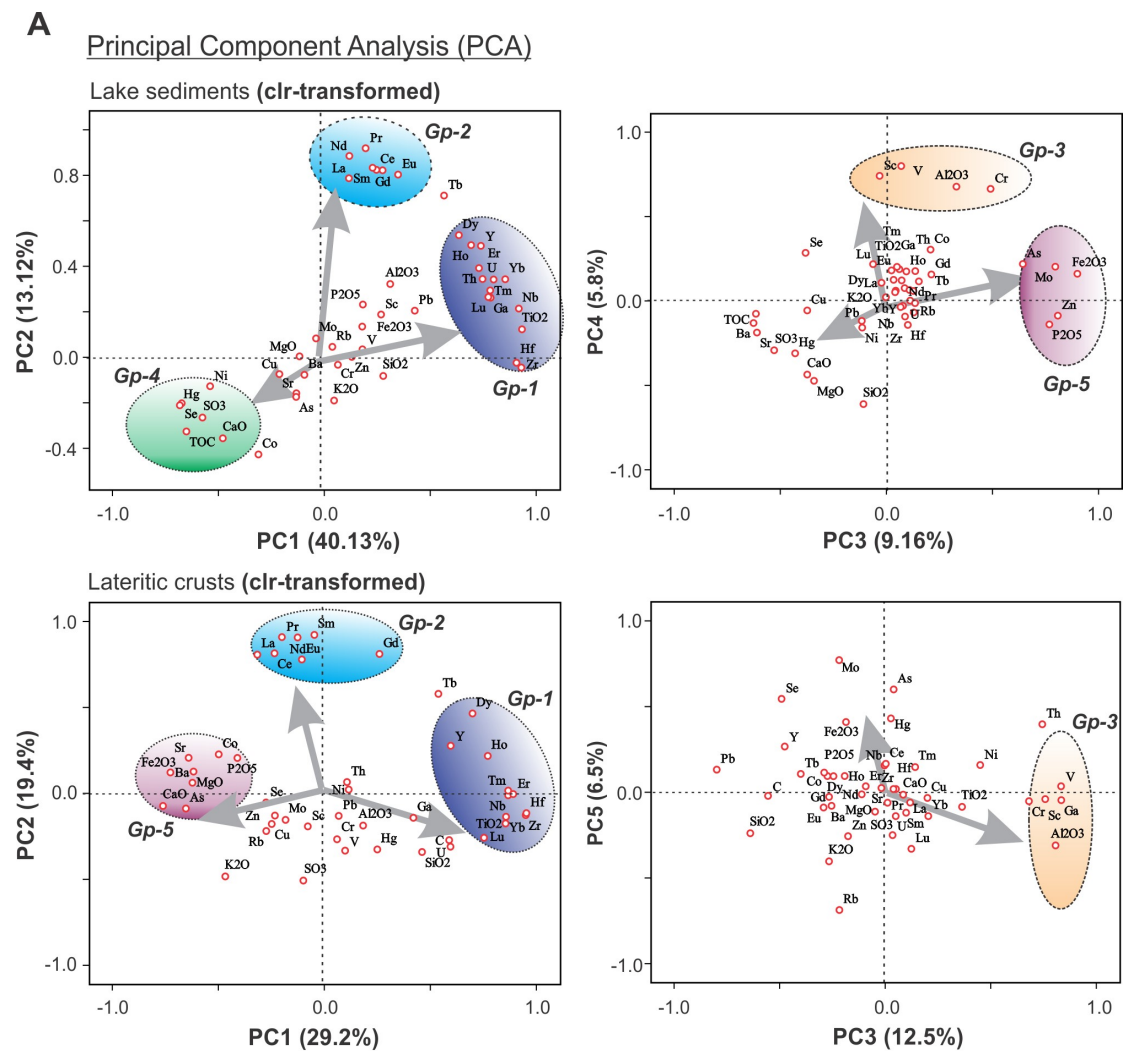

B
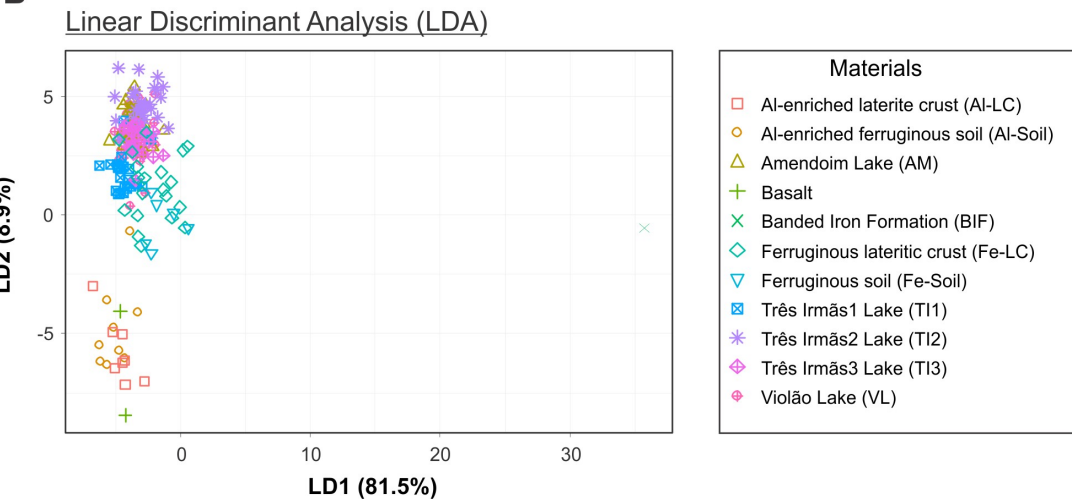

Fig. 3. Principal component analysis (PCA) biplot of PC1 vs PC2 and PC3 vs PC4 for all lake sediments and catchment lateritic crusts, based on centered log-ratio (clr) transformed data, showing the different geochemical associations and the major detritic signatures similar between them (A); and Linear discriminate analysis (LDA) showing the distribution of lake sediments with 
relationship with catchment basin materials (B) (modified from Sahoo et al., 2019).

The detritic association of $\mathrm{Gp} \mathrm{1,2}$ and 3 similar with catchment rocks indicates a strong influence of catchment basin lithology and laterization process. Multivariate analysis such as Linear Discriminant Analysis (LDA) further indicates that detritic sediments are not directly derived from the parent rocks (Fig. 3b), but are well correlated with the underlying weathered crusts (mainly ferruginous) and soils, while ferruginous laterite crusts are the major source of detrital sediments. This inference clearly demonstrates that lake sediments can be a potential tool for identifying and describing catchment processes and basin lithology.

The geochemical proxies further support the interpretation of depositional conditions and revealed that sediments are deposited under oxic depositional enrichment (Sahoo et al., 2015, 2016a), and the elements in sediments have less post-depositional changes, despite having high enrichment of TOC and Fe. All these fundamental knowledge of the modern lake sedimentary processes of Amazonian ULs and its lake catchment interactions thus can provide a crucial insight for the interpretation of source-sink relationships and paleoclimate reconstruction in future studies.

Principal component analysis (PCA) performed on centred log transformed (clr) data was evaluated the relationships of the geochemistry of the bottom sediments among filled lakes (Fig. 4). In general, sediments from each zone show distinguished characteristics. Bocaína (LB) lakes were mostly differentiated from others as they loaded weakly on PC1 and negatively on PC2. It is related to the lateritic crusts of this area that were formed mostly from metavolcanic rocks. Thus, the lake sediments have higher concentrations of $\mathrm{Al}, \mathrm{Ti}, \mathrm{Cr}, \mathrm{V}, \mathrm{Sc}$ and associated elements. Filled lakes of the Serra Sul have widely varied in geochemical compositions, part of the samples positively loaded PC1 and part of loaded on PC2. This is mostly associated with Fe as well as $\mathrm{Si}$, indicating that the crusts developed mainly from iron formations, which have significant concentrations of Fe, while Si contribution from BIF. Sediments from ST02 Lake show mostly negatively loading on PC1 and positively on PC2. This is partly associated with Fe suggesting that the crusts are similar with Serra Sul, but the high enrichment of $\mathrm{Co}, \mathrm{Cu}, \mathrm{Mo}, \mathrm{P}, \mathrm{Cr}$ and $\mathrm{P}$ in these sediments indicates strong influence of mafic rocks, which is not exactly similar with Bocaína.

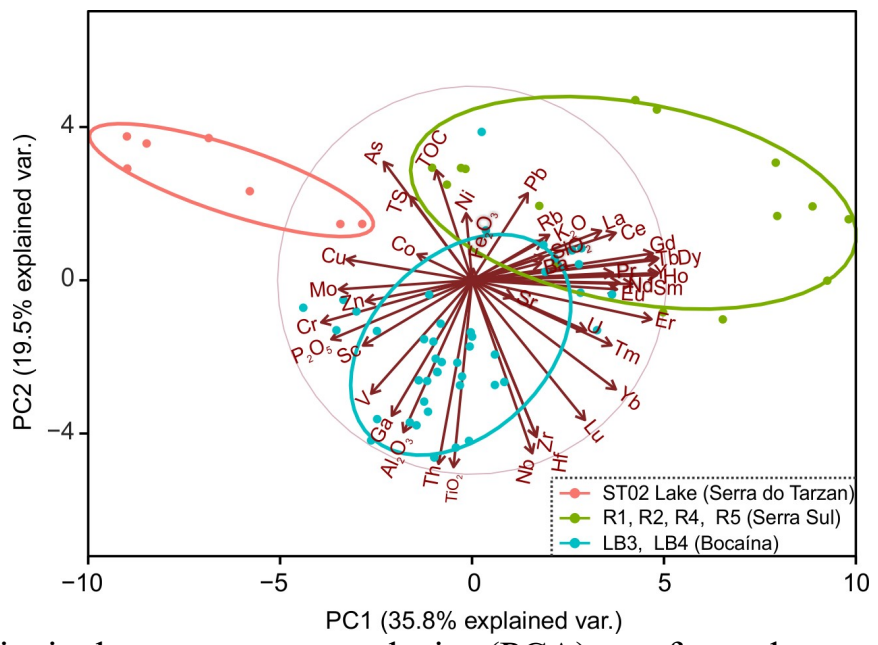

Fig. 4. Principal component analysis (PCA) performed on centred log transformed (clr) data for all filled lakes (sediment cores). 


\section{Environmental influences on limnology and water quality}

In closed lake basin, local geology and seasonal climate are the major factors controlling the physical and chemical characteristics of waters such as temperature, thermal stratification, lake levels and nutrient availability (Catalan and Rondon 2016; Sahoo et al., 2017b). These parameters can have a significantly influence on lake trophic states, phytoplankton assemblage as well as the overall planktonic abundance (Molisani et al., 2010). To address these issues, Sahoo et al. (2017b) presents the first integrative approach of limnological study on the ULs in the Carajás region. The results show that waters were mostly acidic in nature (avg. $\mathrm{pH}$ 4.9-5.9), with high total Fe (up to $1.52 \mathrm{mg} / \mathrm{L}$ ) and low $\mathrm{SO}_{4}$ and other metal concentrations. Low $\mathrm{pH}$ can be explained by the absence of base and by the ferruginous lateritic nature of the catchment, as well as high sedimentary organic carbon which releases $\mathrm{CO}_{2}$ and $\mathrm{H}_{2} \mathrm{~S}$ by bacterial decomposition that make the water acidic (Wetzel, 2001). The main reason behinds the high levels of $\mathrm{Fe}$ is the weathering and erosion of ferruginous soils and laterites crusts. The chemical compositions of these lakes indicate catchment geology is one of the dominating factors influencing water chemistry.

These ULs are shallow, weakly stratified (Fig. 5a), and classified as polymictic type, which controlled vertical mixing of limnological parameters (Sahoo et al., 2017b). Although water quality index (WQI) shows good water quality and high similarity among the studied lakes, the trophic state of these lakes varied significantly from ultraoligotrophic to eutrophic states (Fig. 5b), with lower values observed for Amendoim Lake (Sahoo et al., 2017b). High trophic states are due to nutrient concentrations, mainly TP (total phosphorous), promoting algal growth. Sources of TP for these lakes are associated with the presence of mafic rocks, and caves with high guano volume (Sahoo et al., 2016b, 2017b). Although, Chl-a and cyanobacteria are mainly influenced by nutrients such as TP, this is not the case for these lakes, rather they are controlled by additional factors such as seasonal climate conditions, specificities of catchment lithology and lake morphology (Sahoo et al., 2017b).

Phytoplankton taxa in the lakes are characterized by small chroococcales groups and desmids together with filamentous algae, more commonly observed in the dry season. Phytoplankton composition also varied among lakes based on differences in water depth and nutrient concentration, which may be regulated, by local factors such as lake depth, nutrient status that may influence the degree of biological response (Sahoo et al., $2017 \mathrm{~b}$ ). This study outcome contributes to understand the common limnological characteristics of Amazonian ULs and its role in controlling geochemical distribution of elements and diagenetic process in sediments. 
A

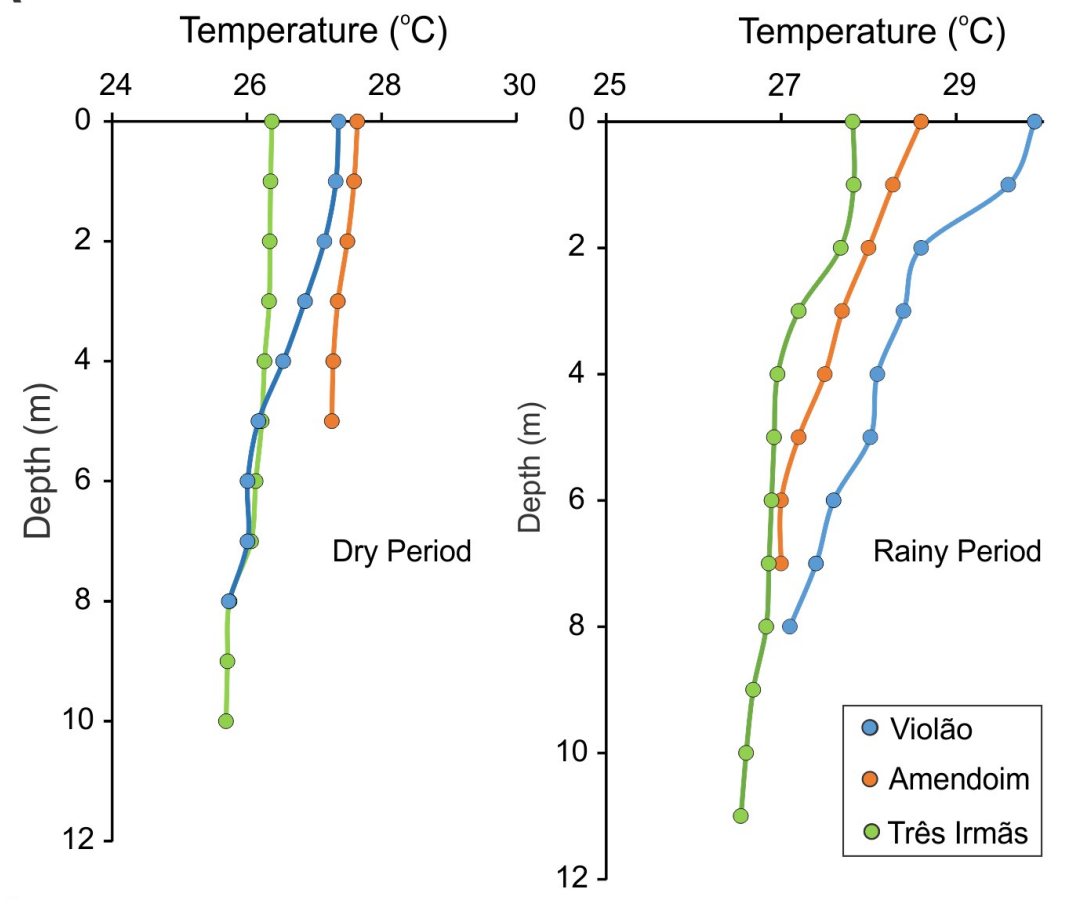

B

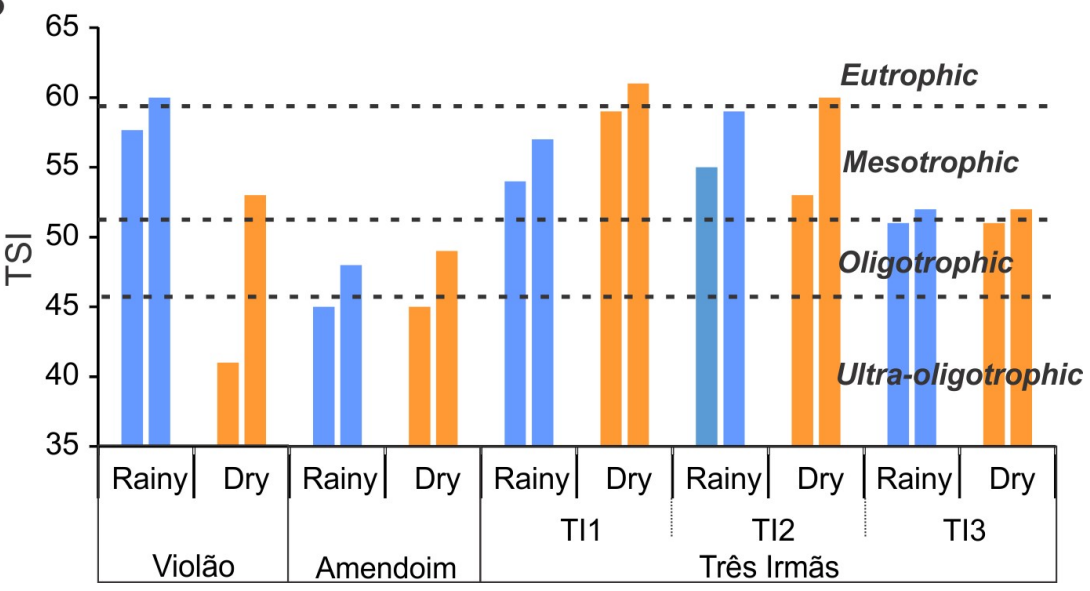

Fig. 5. Vertical temperature profile in Violão, Amendoim and Três Irmãs lakes during the dry and rainy seasons showing the thermal stratification of the lakes (A), and Trophic State Index (TSI) of the lakes during both dry and rainy seasons showing the significant variation of trophic state between lakes (modified from Sahoo et al., 2017).

\section{The role of isotopes in understanding the sources of sediment organic matter}

Sources of organic matter to ULs may be highly variable deriving from vegetation cover of the catchment and central basins, as well as lacustrine primary and secondary productivity (Sahoo et al., 2017a). Morphology and morphometry are important attributes for controlling trophic state of ULs of the Carajás region. The mid-altitudinal ranges, very small catchment area and shallow to very shallow central basins make these ULs sensible to eutrophication processes (Silva et al., 2018). Very shallow central basins are favorable to in-situ development of macrophytes. Thus, modern sediments 
from active and filled ULs may present distinct signatures of the carbon and nitrogen isotopes (Fig. 6a-d).

A
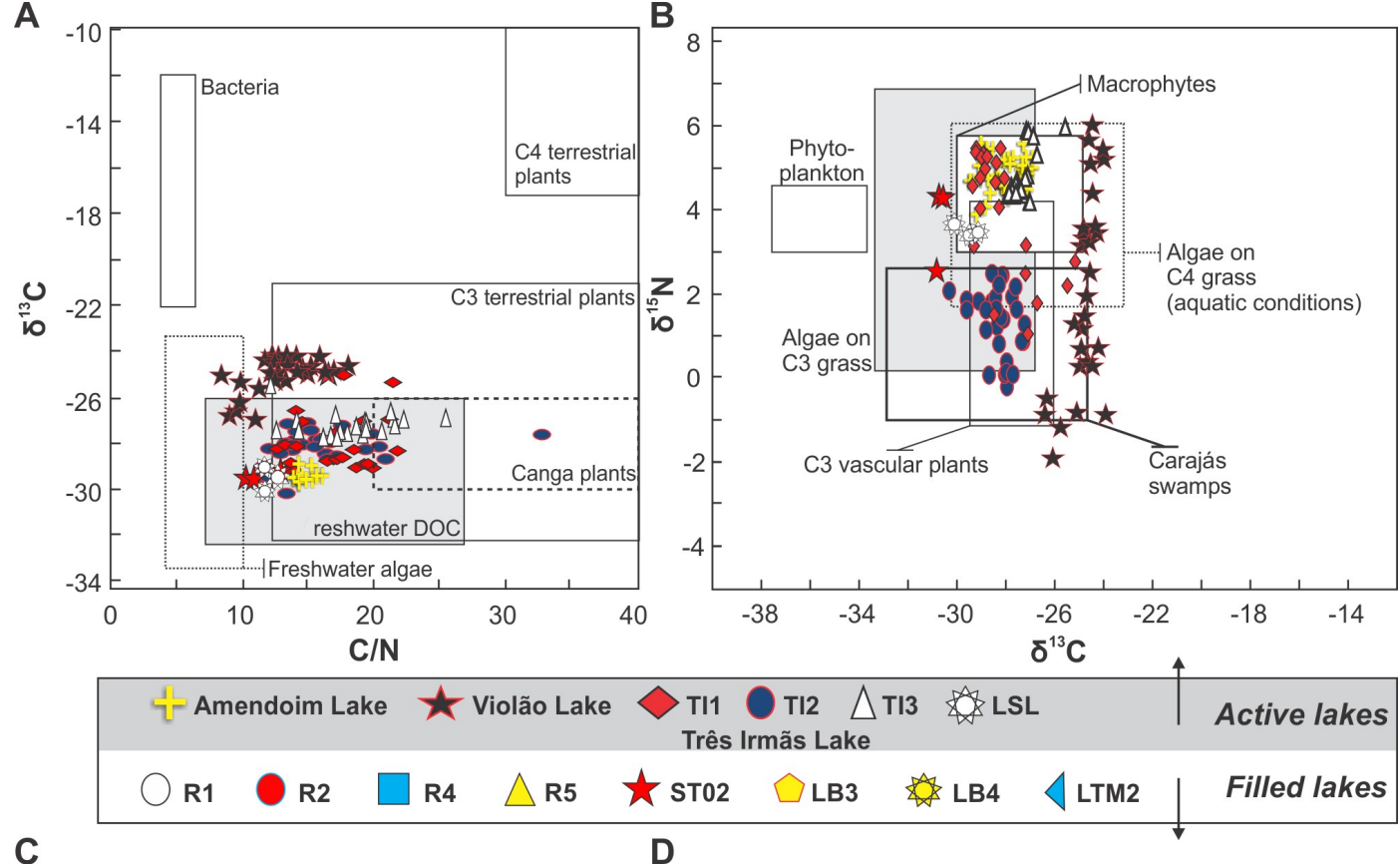

C

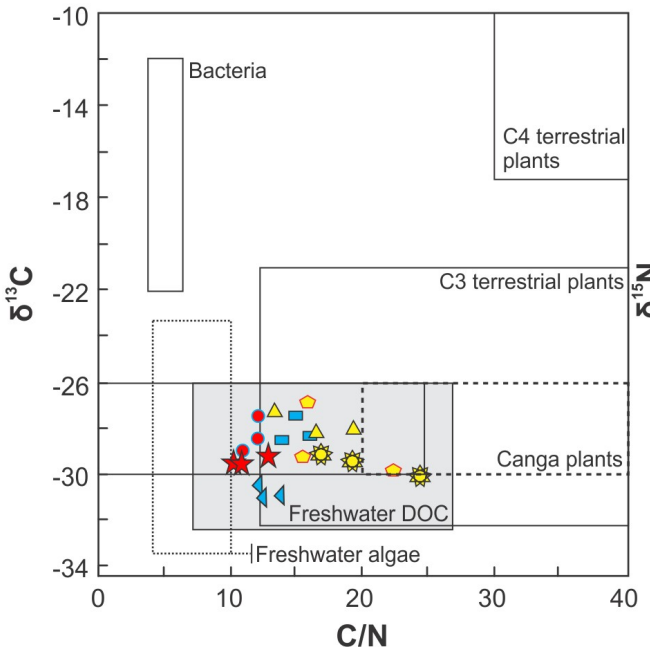

B
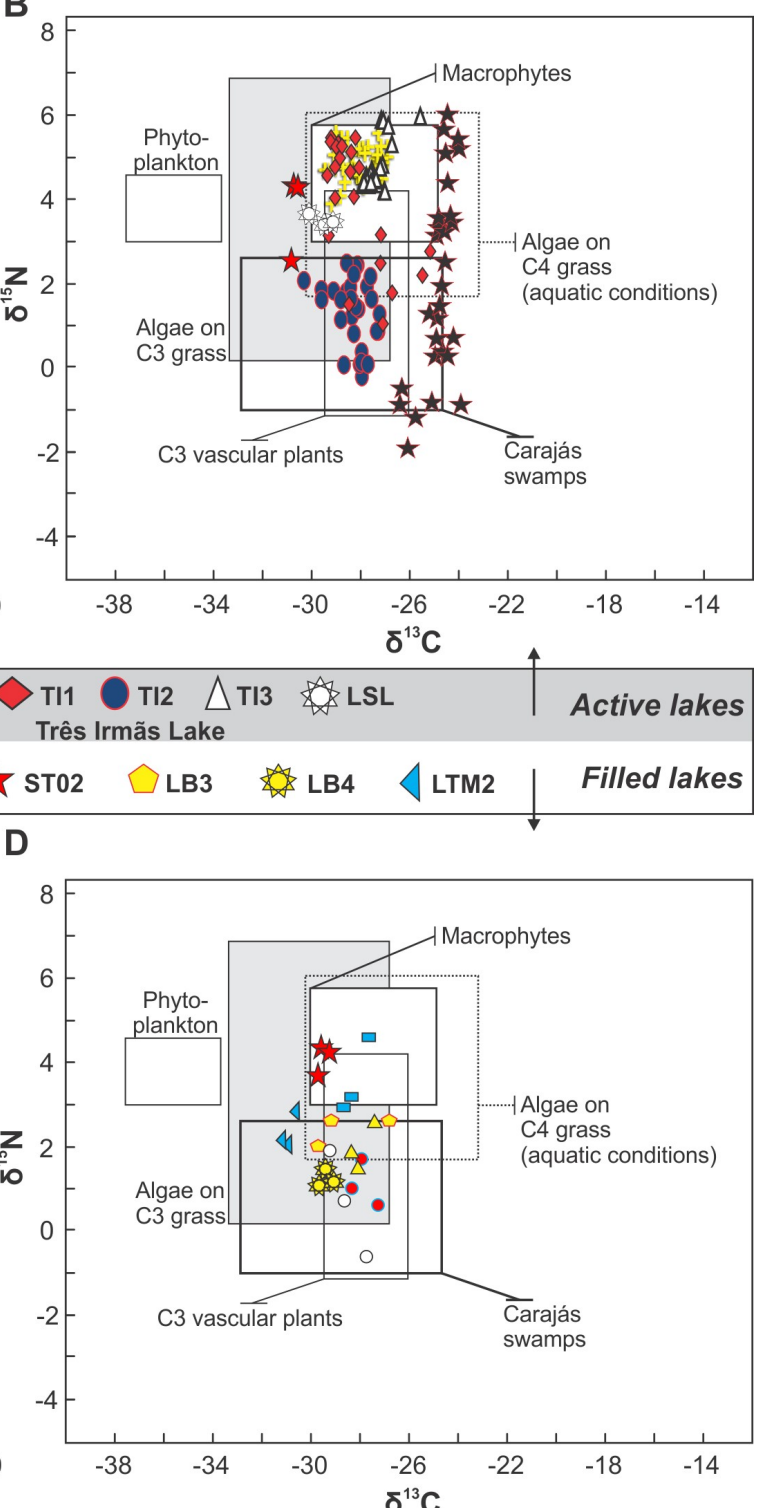

Fig. 6. Binary plot of (a) $\delta^{13} \mathrm{C}$ vs. $\mathrm{C} / \mathrm{N}$ and (b) $\delta^{15} \mathrm{~N}$ vs. $\delta^{13} \mathrm{C}$ of the surficial sediments of the active ULs, and (c) $\delta^{13} \mathrm{C}$ vs. $\mathrm{C} / \mathrm{N}$ and (d) $\delta^{15} \mathrm{~N}$ vs. $\delta^{13} \mathrm{C}$ of sediment cores from filled ULs of the Carajás region (fields based on Deines, 1980; Boutton, 1991; Hamilton and Lewis, 1992; Thornton and McManus, 1994; Meyers, 1997; Brenner et al., 1999; Troxler and Richards, 2009; Smith et al., 2012; Sahoo et al., 2015, 2016a, 2017a; Reis et al., 2017),

The $\delta^{13} \mathrm{C}$ and $\delta^{15} \mathrm{~N}$, and $\mathrm{C} / \mathrm{N}$ data from surficial sediments of the Violão Lake indicate that the organic matter comes from the siliceous sponge spicules, algae, and $\mathrm{C} 3$ vascular forest plants (Sahoo et al., 2015). The latter is dominant in the shallower portion of this lake (arm), with more impoverished $\delta^{15} \mathrm{~N}$. Considering the Amendoim Lake, the stable isotopic compositions are quite homogeneous, and suggest organic sources composed of submerged macrophytes and palms (Sahoo et al., 2016a). More 
diversified sources occur in the Três Irmãs Lake. The isotopic and elemental signatures are indicative of $\mathrm{C} 3$ plants, macrophytes and freshwater DOC, while TI2 Lake has a lower influence from aquatic organic matter, quite similar with the arm of Violão Lake based on $\delta^{15} \mathrm{~N}$ values (Fig. 6a, b).

Filled lakes developed over structured and detrital (R1, R2, R4, R5) and A1-rich crusts (ST02, LB3, LB4, LTM2) are mainly composed by organic matter derived from freshwater DOC, C3 plants and algae, while canga plants are less represented or its signals are diluted with other organic sources (Fig. 6c, d). Enriched values of $\delta^{15} \mathrm{~N}$ indicate slightly higher aquatic influence on LTM2 and ST02 lakes. More impoverished values of $\delta^{13} \mathrm{C}$ occur in LTM2. This site is located into a very narrow plateau with an area of around $0.033 \mathrm{~km}^{2}$ surrounded by HETF. HETF has more profound soils with higher water availability than lateritic crusts. Adaptations to seasonal droughts makes canga plants be characterized by higher water shortage, and consequently, more enriched values of $\delta^{13} \mathrm{C}$ than HETF (Mitre et al., 2018). Thus, the signal from HETF must be predominant in the sedimentary organic matter of LTM2 Lake.

\section{Modern pollen rain using ULs sediments}

Edaphic conditions developed in the plateaus of the Carajás region lead to the formation of islands of canga plants, structurally and compositionally different from the surrounding matrix, with a large number of endemic species (Skirycz et al. 2014; Nunes et al., 2015). Any comparisons with other savanna physiognomies should consider pollination strategies related to environmental conditions (Guimarães et al., 2018a). The pollen signal of HETF may overlap the signal of small savanna due to high production and enhanced dispersal capacity, but this is not always true.

The modern pollen rain of Violão Lake was evaluated using surficial sediments shows significant differences regarding its spatial distribution (Guimarães et al., 2014). Pollen from canga vegetation is predominant in the lake, occurring in eastern and western portions. Pollen grains from HETF and SDF are concentrated in its arm, while algae spores are mainly observed in the central portion. The comparative analysis between floristic inventories of the catchment basin and modern pollen rain indicates that pollen from canga plants are brought into Lake Basin from 'regional' sources (outside the basin). On the other hand, pollen grains from HETF and SDF represent local sources (inside the basin).

Modern pollen rain based on Amendoim Lake, located $\sim 1 \mathrm{~km}$ eastward and $20 \mathrm{~m}$ below the mean altitude of the Violão Lake (Fig. 2), shows that pollen from HETF and SDF are dominant on surficial sediments, despite the widespread abundance of canga plants in its drainage basin. This suggests the role of topographic control and prevailing wind direction on pollen deposition (Guimarães et al., 2017). In the same way, one-year (2015-2016) of pollen data collected from artificial traps installed along the drainage basin of the LTM2 Lake reveal did not indicate overlaps of pollen signal between vegetation types (Fig. 7). These findings based on surficial lake sediments and artificial traps contradict the assumption of D'Apolito et al. (2018) that a clear savanna signal will only be acquired in sites with a large extension of this vegetation type. 

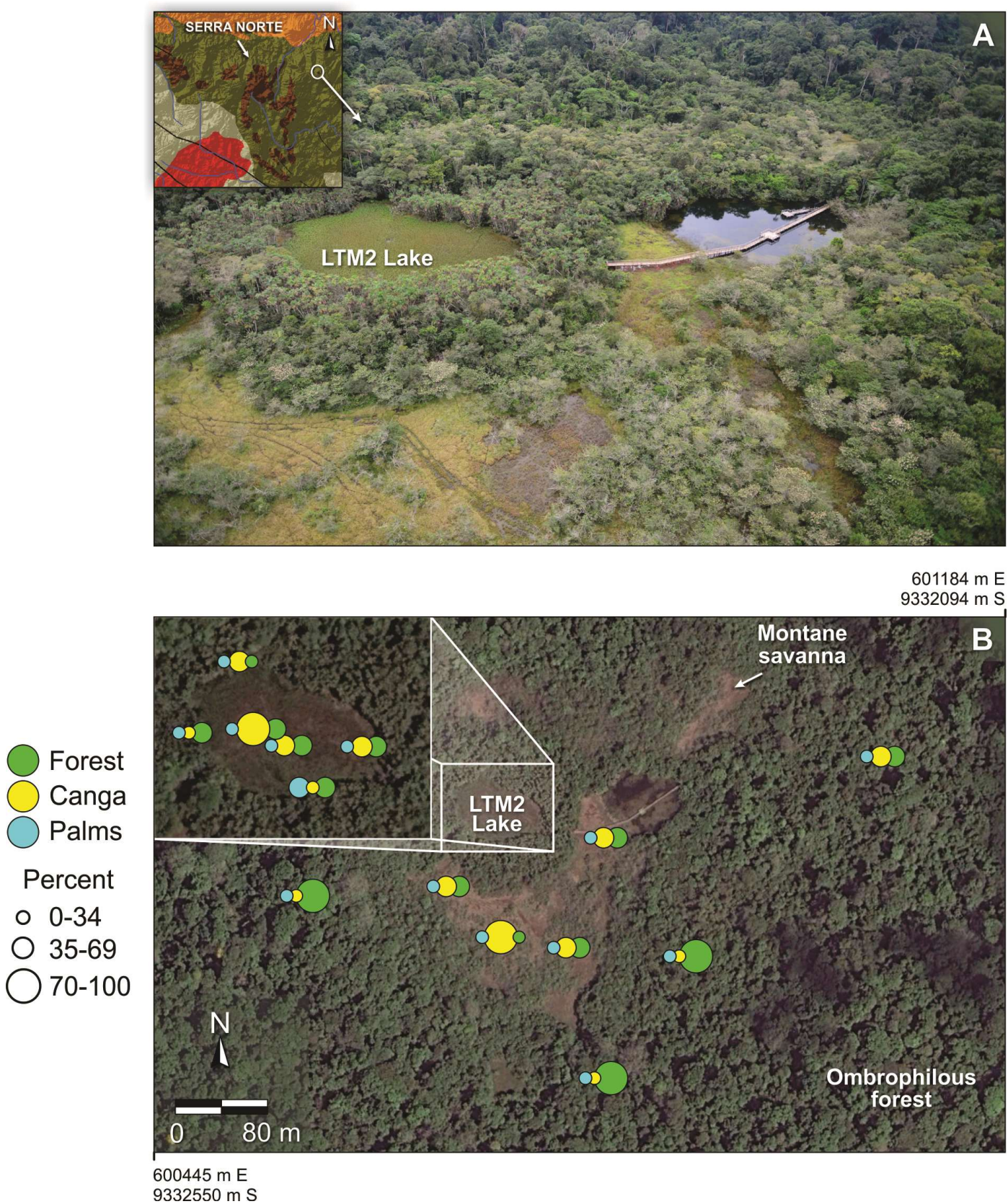

Fig. 7. Modern pollen rain of catchment basin of the LTM2 Lake, Serra Norte dos Carajás (a), showing the annual contribution (in \%) of grains from forest, canga and palms (b).

Amendoim Lake is the unique active and oligotrophic lake of this region (Sahoo et al., 2016b). This trophic condition favored the widespread development of Isoetes cangae, which only occurs in this lake (Pereira et al., 2014; Caldeira et al., 2018). In addition, this species is very well represented on surficial sediments by its microspores (Guimarães et al., 2017). Thus, the use of Isoetes microspores as a proxy for low water levels, eutrophic and drier paleoclimate conditions must be used with caution.

These studies clearly indicate the importance of understanding (1) the ways in which modern pollen grains are transported into lakes, (2) the relationship between pollen and regional or local vegetation signals, (3) the modern vegetation types considering a clear 
taxonomic and ecological determination, coupled with a robust pollen database of the studied site. This approach should precede any effort for paleovegetation reconstruction.

\section{ULs sediments: implication for paleovegetation and paleoenvironmental changes}

Previous palynological studies in sediment cores collected from filled ULs of the Serra Sul dos Carajás indicated drier glacial conditions of the late Pleistocene (Absy et al., 1991; Hermanowski et al., 2012), based on high and low abundance of canga (Poaceae, Borreria, Asteraceae, among others) and forest taxa (e.g. AlchornealAparisthmium, Moraceae and Celtis), respectively. However, these canga taxa in Carajás were generally over-represented (Guimarães et al., 2018a). In edaphically conditioned areas, such as those observed for canga vegetation of Carajás, most of the plants lose their leaves and do not produce flowers during drier months (June to September), remaining in an almost dormant state to save energy due to strong hydric stress (Sahoo et al., 2016b). Thus, high abundance of pollen from overrepresented taxa did not directly indicate expansion of canga plants under drier conditions. In addition, all previous work on Carajás was conducted on swampy grasslands, so most of these records may reflect hydrarch succession and basin-filling rather than a paleoclimate signal (Guimarães et al., 2018a). Considering the effects of diagenesis on glacial deposits of these lakes, siderite beds commonly occur in downprofile and are timely correlated with the supposed savanna (canga) expansion (Absy et al., 1991; Soubies et al., 1991; Guimarães et al., 2016; Reis et al., 2017).

Siderites in ULs of Carajás are associated with post-depositional processes where biologically mediated diagenesis degraded organic material, converting ferric to ferrous iron and generating $\mathrm{CO}_{2}$ that caused massive siderite precipitation (Guimarães et al., 2016). It also influences elemental and isotopic composition of the bulk organic matter (Meyers and Teranes, 2001), as well as strongly degrade biopolymer components, producing selective preservation of pollen grains (Guimarães et al., 2018a). Thus, plants that produce large quantities of pollen, and those that produce high resistant grains may prevail in pollen assemblages (Reis et al., 2017).

This suggests that other proxies must be carefully integrated and analyzed with pollen data to understand paleoenvironmental and paleoclimate conditions of this region. Furthermore, ULs of Carajás region has different geomorphological setting (Silva et al., 2018), which influences sediment yield and geochemical characteristics, resulting from complex basin processes from sources to sinks of the sediments.

Active lakes (Três Irmãs, Violão and Serra Leste) do not present problems with hydrarch succession and basin-filling in their deposits. Absence of woody roots and physical or geochemical indicators of subaerial exposure indicate that these lakes never dried up during the last $50 \mathrm{ka}$ cal BP. Based on geochemical proxies, the detrital fraction (Al and $\mathrm{Ti}$ ) provides insight about climatic conditions prevailing in source areas and mechanisms involved in the transport of materials within the basin (Guimarães et al. 2016). When rainfall is strong enough it can cause high erosion and high detrital input to lakes (Oliveira et al., 2009), as shown by an increase of $\mathrm{Al}$ and $\mathrm{Ti}$. Ti and $\mathrm{K}$ are typically associated with clays and increase in the $\mathrm{Ti} / \mathrm{K}$ suggest high amounts of weathered clay minerals deposited during high water stands and wetter periods (Hodell et al., 1998). Therefore, $\mathrm{Al} / \mathrm{K}$ and $\mathrm{Ti} / \mathrm{K}$ are very well correlated and slight increased values seems to be fitted with Heinrich Stadials (HS) 1-3. This may be attributed to an increased precipitation due to a strengthening of the South American summer monsoon due to a change in the Atlantic interhemispheric sea surface temperature (SST) gradient 
(Zhang et al., 2016), also affecting eastern Amazon. It interrupted a generalized drier period in the beginning of the LGM until around $13 \mathrm{ka}$ cal BP (Fig. 8). Carbon and nitrogen isotopes indicates continuous predominance of $\mathrm{C} 3$ plants and freshwater DOC, except for Violão Lake that presented more enriched values throughout the late Pleistocene until $20 \mathrm{ka}$ cal BP. This may be indicative of the presence of siderite nodules (Guimarães et al., 2016; Reis et al., 2017), which massively formed in the Violão Lake at around 30 to $35 \mathrm{ka}$ cal $\mathrm{BP}$, and dilution with algae on $\mathrm{C} 4$ grass environment (aquatic conditions).

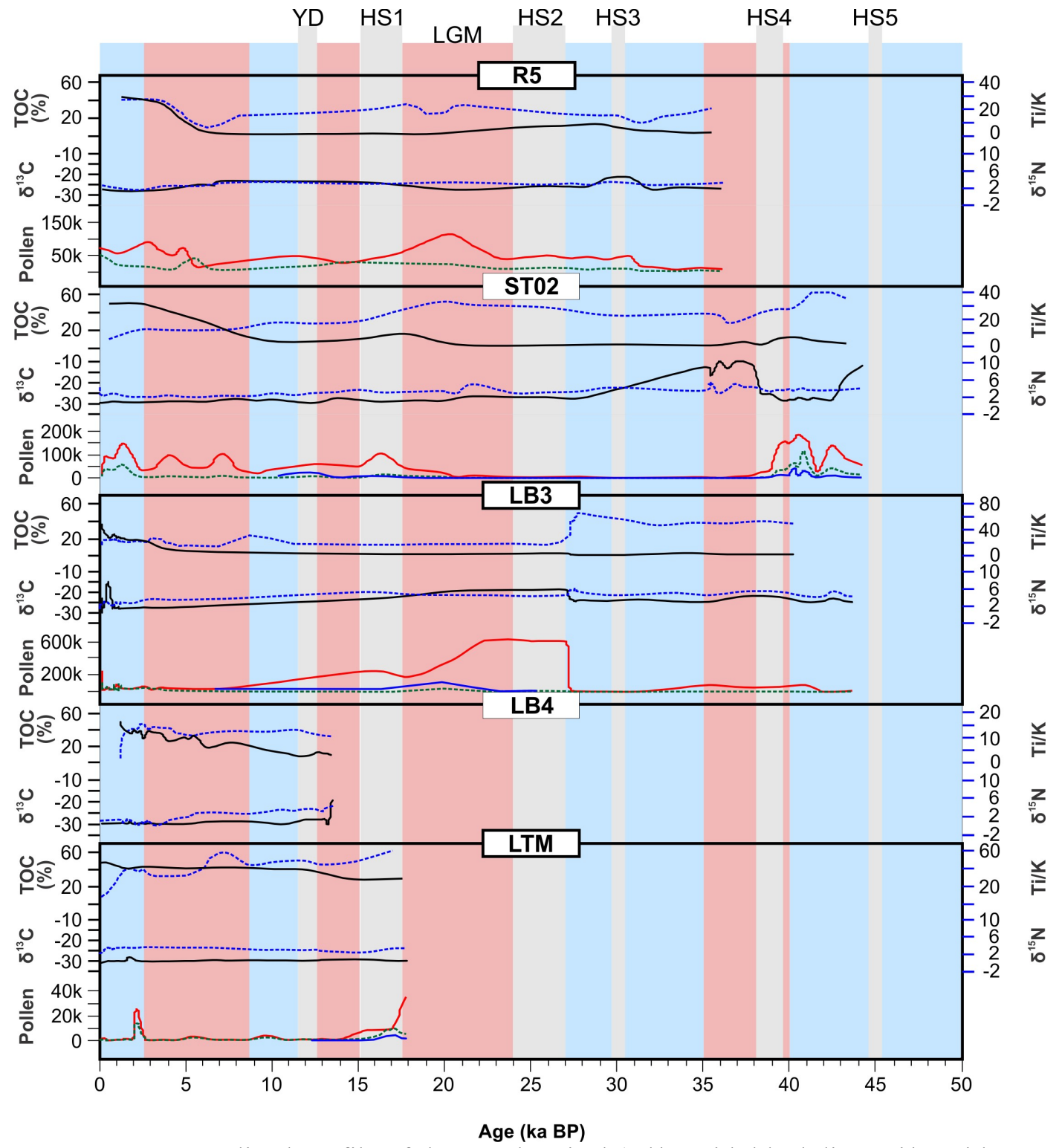

Fig. 8. Generalized profile of the geochemical (Al/K with black line, Ti/K with blue-dashed line), isotopic ( $\delta^{13} \mathrm{C}$ with black line, $\delta^{15} \mathrm{~N}$ with blue dashed line), and pollen (canga vegetation with red line, forest with green line and cooladapted taxa with blue line) data of active (3 Irmãs, Violão and Serra Leste) and filled (R1, R2, R4, R5, ST02, LB3, LB4 and LTM) lakes. Light blue and red vertical bars represent wet and dry lacustrine phases in the ULs of Carajás 
according to Sifeddine et al. (2001), Guimarães et al. (2016, 2018b), Reis et al. (2017). Divided in 2 parts.

High $\mathrm{Al} / \mathrm{K}$ and $\mathrm{Ti} / \mathrm{K}$ values infer high amount of weathered clay minerals deposited during the high water stands and wetter period in the Holocene deposits of the active lakes, except for the relatively low ratios around the mid-Holocene (Fig. 8). In general, Increase of $\mathrm{Al} / \mathrm{K}$ and $\mathrm{Ti} / \mathrm{K}$ ratio is an indication of high amounts of weathered clay minerals, which can be deposited during high water stands and occurred during wetter periods. This will also be favored during the cycling of dry to wet period. During Dry periods, occasional rainfall leads to weathering and these materials transported during heavy rainfall event. Additionally, pollen data of the Serra Leste covering the last $15 \mathrm{ka}$ cal BP showed that canga vegetation and forests concomitantly contracted and expanded in a cyclic pattern during the last $5 \mathrm{ka}$ cal BP. This is a clear indicative of the predominance of a strong millennial climate seasonality.

Filled lakes over structured and detrital (R1, R2, R4, R5) and Al-rich crusts (ST02, LB3, LB4, LTM2) are more influenced by the basin-filling effect. In this way, the establishment of modern swampy conditions (final filling stage) varied according sites. These conditions were attained in the R1, R5, ST02 and LTM2 lakes around $10 \mathrm{ka} \mathrm{cal}$, while R2 and LB3 lakes at $5 \mathrm{ka}$ cal BP, and R4 and LB4 at $2 \mathrm{ka}$ cal BP, which is clearly observed from their TOC, carbon and nitrogen isotopic profiles (Fig. 8). The detrital fraction of these cores follows the cycles of lake level and paleoclimate changes in Carajás region, with good records for the LGM and mid-Holocene, as described by relatively low $\mathrm{Ti} / \mathrm{K}$. However, differently from the active lakes, the $\mathrm{Ti} / \mathrm{K}$ profiles between the late Pleistocene and Holocene deposits of the filled lakes cannot be compared since the latter was represented by modern swampy condition. In other words, swamps developed on lakes under low accommodation space when accommodation angle (measured between lake margins and depocenter) decreases at a point restricting to the deposition of detrital materials from runoff to lake margins.

Dryness with subaerial exposure of lacustrine deposits were observed on ST02 Lake during the LGM, and on LB3 and R2 lakes during the mid-Holocene. However, C4 plants were never predominant in the Carajás region, except for the LB3 area that record canga expansion with C4 plants during the LGM, without siderite influence (Fig. 8). Siderites were formed between around 35 to $30 \mathrm{ka}$ cal BP on R5 and ST02 lakes, and during the LGM on R1 and R2 lakes. Serra da Bocaína Lakes do not present iron carbonates such as siderite, which may be related by the different depositional conditions as well as lower abundance of Fe in crust, which leads to lower aqueous iron (Lemos et al., 2007; Kimberley 1989).

Cool-adapted taxa widespread developed along the Carajás region and occurred all over the late Pleistocene until around $7 \mathrm{ka}$ cal, with higher abundance observed before $40 \mathrm{ka}$ cal BP. This is not indicative that colder periods occurred during this period. In fact, most of the LGM deposits were not suitable for high pollen concentration due to the sediment redox condition influenced by diagenetic changes, except for the LB3 Lake that recorded higher abundance of cool-adapted taxa during LGM.

The Interpretation of speleothem data from Paraíso cave in eastern Amazonia indicate wetter climate conditions than present at around 6 ka cal BP (Wang et al., 2017). This contradicts a long set of paleoclimate studies in the Carajás region, that indicates dominance of montane savanna and SDF during the mid-Holocene under drier climate conditions (Absy et al., 1991; Sifeddine et al., 2001; Cordeiro et al., 2008; Hermanowski et al., 2014; Guimarães et al., 2016, Reis et al., 2018; Guimarães et al., 2018b). Assumptions about the Holocene pollen assemblage of Carajás only reflect 
canga vegetation with small signals from HETF, then reflecting local changes on the plateau itself and making difficult any regional scale vegetation changes (Smith and Mayle, 2017), must be viewed with caution. Smith and Mayle (2017) authors based their assumptions on the modern pollen rain of the Violão Lake (Guimarães et al., 2014), while the modern pollen rain of the Amendoim Lake shows the opposite, with predominance of the pollen signal from HETF (Guimarães et al., 2017). Thus, it depends on the topographic position of each lake, wind direction among others factors (Guimarães et al., 2018a).

Drier mid-Holocene on Carajás region was proposed by Sifeddine et al. (2001), Cordeiro et al. (2008), Guimarães et al. (2016), Reis et al. (2018), Guimarães et al. (2018b) mainly based on multi-elemental and organic isotope geochemistry with strong indications of hydric deficit, low weathering and sedimentation rates. In addition, LB3 and $\mathrm{R} 2$ lakes ( $\sim 40 \mathrm{~km}$ distant from each other) were sub aerially exposed during this period with full formation of iron oxides and mud cracks (Figure A.2). The drier midHolocene event was widespread indicated along the southern tropics (Cross et al. 2000; Seltzer et al. 2000; Mayle and Power 2008; Cordeiro et al. 2008; Guimarães et al. 2012; Prado et al. 2013), and by numerical simulations (Maksic et al., 2018). This may be a consequence of low insolation, which induced a less effective land-sea contrast, reducing South Atlantic Convergence Zone intensity and weaker South American Monsoon System (SAMS) (Prado et al., 2013; Maksic et al., 2018).

\section{Conclusions}

The multidisciplinary research approach compiled in this review helps to clarify some key doubts about the formation of the Carajás, as well as the apparent mismatches of plant and paleoclimate dynamics during the last $50 \mathrm{ka}$ cal BP. The ULs were formed by structural and dissolution of the lateritic crusts during the late Cenozoic, and possibly start to fill with sediment during the Quaternary. The study of the modern environments of deposition allowed the calibration of the down-profile data from lake deposits. Thus, it is possible to relate detritic facies with predominant chemical weathering and peat facies with swampy conditions, high primary productivity or macrophytes development under ultra-oligotrophic conditions, depending of the accommodation space. The cyclical pattern of the sediment deposition with alternating beds of mud, peat and siderites reveals that paleoclimate seasonality was stronger during the Holocene than the previous epoch, which was clearly evidenced by stratigraphy, multi-elemental and isotope geochemistry, and pollen data. ULs were strongly influenced by drier paleoclimate conditions of the LGM and mid-Holocene with very low detrital inflow, subaerial exposure of lake deposits and large formation of siderites (late Pleistocene). However, there is no signal of widespread expansion of savanna during the studied period.

Supplementary Material: Table A.1. General description of the surface sediment samples and sediment cores collected from the upland lakes of the Carajás region; Table A.2. Radiocarbon dates (AMS) of the samples from Carajás region; Figure A.1. Graphic sedimentary Log of the active lakes: LTI3 (3 Irmãs-S11), LV2 (Violão-S11), LSL (Serra Leste); and inactive lakes: R1, R2, R4 and R5 (S11). Continued; Figure A.2. Graphic sedimentary Log of the inactive lakes:ST2 (Serra do Tarzan), LB3 and LB4 (Serra da Bocaína), LTM2 (Lagoa Trilha da Mata-Serra Norte). 
Author contributions: JTFG, PKS and PWMSF contributed for conceptualization, data curation, formal analysis, original draft and review \& editing; TMR did the formal analysis and provided resources; WFBJ, LSR, MMJCF, KLS and ASL work on formal analysis; MSS, VEC, and RD worked with supervision and review \& editing.

Acknowledgments: This study has been funded by Vale Institute of Technology, CNPq (479182/2012-4; 442088/2014-0) and FAPESP (2017/04994-1). The first (JTFG) and third (PWMSF) authors were supported by $\mathrm{CNPq}$ through research scholarship (302839/2016-0, 306450/2013-5, respectively). Authors are also thankful to the members of DIPF, DIFN, S11D of Vale S.A. for field support and scientific discussions. This project was carried out in the National Forest of Carajás under permission of IBAMA (SISBIO 35594-2).

\section{References}

Absy, M.L., Cleef, A., Fournier, M., Martin, L., Servant, M., Sifeddine, A., Ferreira da Silva, M., et al., 1991. Mise en évidence de quatre phases d'ouverture de la forêt dense dans le Sud-Est de l'Amazonie au cours des 60000 dernières années: première comparaison avec d'autres régions tropicales. Comptes rendus de l'Académie des Sciences. Série 2, Mécanique, Physique, Chimie, Sciences de l'univers, Sciences de la Terre 312, 673-678.

Arruda, D.M., Schaefer, C.E.G.R., Fonseca, R.S., Solar, R.C., Fernandes-Filho, E.I., 2018. Vegetation cover of Brazil in the last $21 \mathrm{ka}$ : New insights into the Amazonian refugia and Pleistocenic arc hypotheses. Global Ecology and Biogeography 27, 47-56.

Barros, C.E.M., Nascimento, V.M., Medeiros Filho, C.A., 2010. Revisão da estratigrafia das rochas da Serra Leste, Pronvíncia Mineral de Carajás. Revista Brasileira de Geociências 40(2), 167-174.

Blaauw, M., Christen, J.A., 2011. Flexible palaeoclimate age-depth models using an autoregressive gamma process. Bayesian Anal. 6, 457-474.

Brenner, M., Whitmore, T.J., Curtis, J.H., Hodell, D.A., Schelske, C.L., 1999. Stable isotope $(\delta 13 \mathrm{C}$ and $\delta 15 \mathrm{~N})$ signatures of sedimented organic matter as indicators of historic lake trophic state. Journal of Paleolimnology 22(2):205-221

Boutton, T.W., 1991. Stable carbon isotope ratios of natural materials: II. Atmospheric, terrestrial, marine, and freshwater environments. In: Coleman DC, Fry B (eds) Carbon isotope techniques. Academic press Inc., New York, pp 173-185.

Bush, M.B., Oliveira, P.E., Colinvaux, P.A., Miller, M.C., Moreno, J.E., 2004. Amazonian palaeoecological histories: one hill three watersheds. Palaeogeogr. Palaeoclimatol. Palaeoecol. 214, 359-393.

Caldeira, C.F., Abranches, C.B., Gasutauer, M., Ramos, S., Guimarães, J.T.F., Pereira, J.B.S., Siqueira, J.O., 2019. Sporeling regeneration and ex situ growth of Isoëtes cangae (Isoetaceae): Initial steps towards the conservation of a rare Amazonian quillwort. Aquatic Botany 152, 51-58.

Catalan, J., Rondón, J.C.D., 2016. Perspective for an integrated understanding of tropical and temperate high-mountain lakes. J Limnol 75, 215-234.

CETESB, 2006. Dispõe sobre a homologação da revisão da Norma Técnica L5.303 Fitoplâncton de Água Doce - Métodos Qualitativo e Quantitativo (Método de Ensaio) dez/2005. Companhia de Tecnologia de Saneamento Ambiental, Secretária de Meio Ambiente, Estado de São Paulo. (http://www.bmn.com.br/plan-leg/ma/estsp/decis/cetesb42-06.pdf). Accessed on 11/05/2015. 
Colinvaux, P.A., Irion, G., Räsänen, M.E., Bush, M.B., Nunes de Mello, J.A.S., 2001. A paradigma to be discarded: geological and paleoecological data falsify the HAFFER \& PRANCE refuge hypothesis of Amazonian speciation. Amazoniana 16, 609-646.

Cordeiro, R.C., Turcq, B., Suguio, K., Oliveira da Silva, A., Sifeddine, A., Volkmer, C., 2008. Holocene fires in East Amazonia (Carajás), new evidences, chronology and relation with palaeoclimate. Glob. Planet. Change 61, 49-62.

Costa, L.P., 2007. Caracterização das sequências metavulcanossedimentares da porção leste da Província Mineral de Carajás (PA) (Master Thesis). Instituto de Geociências - Universidade Federal de Minas Gerias (IG-UFMG), p. 195.

Costa, M.L., Carmo, M.S., Behling, H., 2005. Mineralogia e geoquímica de sedimentos lacustres com substrato laterítico na Amazônia Brasileira. Revista Brasileira de Geociências 35(2), 165-176.

Cross, S.L., Baker, P.A., Seltzer, G.O., Fritz, S.C., Dunbar, R.B., 2000. A new estimate of the Holocene lowstand level of Lake Titicaca, central Andes, and implications for tropical palaeohydrology. Holocene 10, 21-32.

D'Apolito C, Latrubesse EM and Absy ML (2018) Results confirm a relatively dry setting during the last glacial (MIS 3 and LGM) in Carajás, Amazonia: A comment on Guimaraes et al. The Holocene 28(2), 330-331.

Deines, P., 1980. The isotopic composition of reduced organic carbon. In: Fritz, P., Fontes, J.C. (Eds.), Handbook of Environmental Isotope Geochemistry e the Terrestrial Environment. Elsevier, Amsterdam, pp. 329-406.

EPA, 2004. Method 9060A - Total organic carbon. 5P. Revision 1. United States Environmental Protection Agency.

Faegri, K., Iversen, J., 1989. Textbook of Pollen Analyses. Wiley, Chichester.

Gosling, W.D., Mayle, F.E., Killeen, T.J., et al., 2003. A simple and effective methodology for sampling modern pollen rain in tropical environments. The Holocene 13(4), 613-618.

Guimarães, J.T.F., Cohen, M.C.L., Pessenda, L.C.R., França, M.C., Smith, C.B., Nogueira, A.C.R., 2012. Mid and late Holocene sedimentary process and palaeovegetation changes near the mouth of the Amazon River. Holocene 22, 359-370.

Guimarães, J.T.F., Souza-Filho, P.W.M., Alves, R., Souza, E.B., Costa, F.R., Reis, L.S., Sahoo, P.K., Manes, C.L.O., Silva Junior, R.O., Oti, D., Dall'Agnol, R., 2014. Source and distribution of pollen and spores in surface sediments of a plateau lake in south-eastern Amazonia. Quat. Int. 352, 181-196.

Guimarães, J.T.F., Sahoo, P.K., Souza-Filho, P.W.M., Maurity, C.W., Silva, J.R.O., Costa, F.R., Dall'agnol, R., 2016. Late Quaternary environmental and climate changes registered in lacustrine sediments of the Serra Sul de Carajás, southeast Amazonia. J. Quatern. Sci. 31, 61-74.

Guimarães, J.T.F., Rodrigues, T.M.R., Reis, L.S., de Figueiredo, M.M.J.C., da Silva, D.F., Alves, R., Giannini, T.C., Carreira, L.M.M., Dias, A.C.R., Silva, E.F., Sahoo, P.K., Silva, M.S., Souza-Filho, P.W.M., 2017. Modern pollen rain as a background for palaeoenvironmental studies in the Serra dos Carajás, southeastern Amazonia. Holocene 27(8), 1055-1066.

Guimarães, José Tasso Felix; Sahoo, P. K.; Reis, L.S., 2018a. Modern pollen rain raises doubts about the intensity and extension of the Last Glacial Cycle in Carajás: A reply to D'Apolito et al.. Holocene 28, 332-335.

Guimarães, J.T.F., Sahoo, P.K., Souza-Filho, P.W.M., de Figueiredo, M.M.J.C., Reis, L.S., Silva, M.S., Rodrigues, T.M.R., 2018b. Holocene history of a lake filling and 
vegetation dynamics of the Serra Sul dos Carajás, southeast Amazonia. An. Acad. Bras. Ciênc. DOI: 10.1590/0001-3765201720160916.

Hamilton, S.K., Lewis Jr., W.M., 1992. Stable carbon and nitrogen isotopes in algae and detritus from the Orinoco River floodplain, Venezuela. Geochim. Cosmochim. Acta $56,4237-4246$.

Hasberg, A.K.M., Bijaksana, S., Held, P., Just, J., Melles, M., Morlock, M.A., Opitz, S., Russell, J.M., Vogel, H., Wennrich, V. 2018. Modern Sedimentation processes in Lake Towuti, Indonesia, revealed by the composition of surface sediments. Sedimentology, 2018. DOI: 10.1111/sed.12503.

Hermanowski, B., Costa, M.L., Carvalho, A.T., et al. 2012. Palaeoenvironmental dynamics and underlying climatic changes in southeast Amazonia (Serra Sul de Carajás, Brazil) during the late Pleistocene and Holocene. Palaeogeography, Palaeoclimatology, Palaeoecology 365-366, 227-246.

Hermanowski, B., Costa, M.L., Behling, H., 2014. Possible linkages of palaeofires in southeast Amazonia to a changing climate since the Last Glacial Maximum. Veg. Hist. Archaeobot. 24, 279-292.

Hodell, D.A., Schelske, C.L., 1998. Production, sedimentation, and isotopic composition of organic matter in Lake Ontario. Limnology and Oceanography 43, 200214.

Kimberley, M.M., 1989. Exhalative origins of iron formations. Ore Geology Reviews 5, 13-145.

Lemos, V.P., Costa, M.L.C., Lemos, R.L., de Faria, M.S.G., 2007. Vivianite and siderite in lateritic iron crust: an example of bioreduction. Quimica Nova 30, 36-40.

Lopes, M.N.G., Souza, E.B., Ferreira, D.B.D.S. 2013. Climatologia regional da precipitação no estado do Pará. Revista Brasileira de Climatologia 12(1), 84-102.

Lopes, P.M., Caliman, A., Carneiro, L.S., Bini, L.M., Esteves, F.A., Farjalla, V., Bozelli, R.L., 2011. Concordance among assemblages of upland Amazonian lakes and the structuring role of spatial and environmental factors. Ecological Indicators 11, 1171-1176.

Macambira J.B. 2003. O ambiente deposicional da Formação Carajás e uma proposta de modelo evolutivo para a Bacia Grão Pará ( $\mathrm{PhD}$ Thesis)., Instituto de Geociências Universidade Estadual de Campinas (IG-UNICAMP), p. 217.

Maksic, J., Shimizu, M.H., de Oliveira, G.S., Venancio, I.M., Cardoso, M., Ferreira, F.A., 2018. Simulation of the Holocene climate over South America and impacts on the vegetation. The Holocene. https://doi.org/10.1177/0959683618810406.

Maurity, C.W., Kotschoubey, B., 1995. Evolução recente da cobertura de alteraçao no platô N1- Serra dos Carajás-PA: Degradação, pseudocarstificaçao, espeleotemas. Boletim do Museu Paraense Emilio Goeldi. Serie Ciênc. Terra 7, 331-362.

Mayle, F.E., Power, M.J., 2008. Impact of a drier early-mid Holocene climate upon Amazonian forests. Philosophical Transactions of the Royal Society B 363, 1829-1838.

Meyers, P.A., Teranes, J.L., 2001. Sediment organic matter. In: Last, W.M., Smol, JP (Eds.), Tracking Environmental Changes Using Lake Sediment, Vol. 2: Physical and Geochemical Methods. Dordrech,: Kluwer Academic, pp. 239-270.

Meyers, P.A., 1997. Organic geochemical proxies of palaeoceanographic, palaeolimnologic, and palaeoclimatic processes. Org. Geochemist. 27, 213-250.

Mitre, S.K., Mardegan, S.F., Caldeira, C.F., Ramos, S., Furtini Neto, A.E., Siqueira, J.O., Gastauer, M. 2018. Nutrient and water dynamics of Amazonian canga vegetation differ among physiognomies and from those of other neotropical ecosystems. Plant Ecology. Doi: 10.1007/s11258-018-0883-6. 
Molisani, M.M., Barroso, H.S., Becker, H., Moreira, M.O.P., Hijo, C.A.G., Monte, T.M., et al., 2010. Trophic state, phytoplankton assemblages and limnological diagnosis of the Castanhão Reservoir, CE, Brazil. Acta Limnol Bras 22, 1-12.

Moraes, B.C., da Costa, J.M.N., da Costa, A.C.L., Costa, M.H., 2005. Variação espacial e temporal da precipitação no estado do Pará. Acta Amaz. 35, 207-214.

Mormul, R.P., Esteves, F.A., Farjalla, V.F., Bozelli, R.L., 2015. Space and seasonality effects on the aquatic macrophyte community of temporary Neotropical upland lakes. Aquatic Botany 126, 54-59.

Nogueira, A.C.R., Trunckenbrodt, W., Pinheiro, R.L.V., 1995. Formação Águas Claras, Pré-cambriano da Serra dos Carajás: redescrição e redefinição litoestratigráfica. Boletim Museum Paraense Emílio Goeldi 7, 177-197.

Nunes, J.A., Schaefer, C.E.G.R., Ferreira Júnior, W.G., Neri, A.V., Correa, G.R., Enright, N.J., 2015. Soil-vegetation relationships on a banded ironstone 'island', Carajás Plateau, Brazilian Eastern Amazonia. An. Acad. Bras. Ciênc. 87 (4), 2097-2110.

Oliveira, S.M.B., Saia, S.E.M.G., Pessenda, L.C.R. et al., 2009. Lacustrine sediments provide geochemical evidence of environmental change during the last millennium in southeastern Brazil. Chemie Der Erde - Geochemistry 69, 395-405.

Pereira, J.B.S., Salino, A., Arruda, A., Stützel, T., 2016. Two New Species of Isoetes (Isoetaceae) from northern Brazil. Phytotaxa 272 (2), 141-148.

Prado, L.F., Wainer, I., Chiessi, C.M., Ledru, M.P., TURCQ, B., 2013. A midHolocene climate reconstruction for eastern South America. Clim Past 9, 2117-2133.

Reis, L.S., Guimarães, J.T.F., Souza-Filho, P.W.M., Sahoo, P.K., Figueiredo, M.M.J.C., Souza, E.B., Giannini, T.C., 2017. Environmental and vegetation changes in southeastern Amazonia during the late Pleistocene and Holocene. Quaternary International 449, 83-105.

Reimer, P.J., Bard, E., Bayliss, A., Beck, J.W., et al., 2013. IntCal13 and MARINE13 radiocarbon age calibration curves 0-50000 years cal. BP. Radiocarbon 55 (4), 1869-1887.

Rosière C.A., Baars F.J., Seoane J.C.S., Lobato L.M., Lopes L., Souza S.R.C., 2005. Structure and iron mineralisation in the Carajás Province. In: Proceedings Iron Ore 2005, The Australasian Institute of Mining and Metallurgy, Publication Series, 8: 143150 .

Sahoo, P.K., Souza-Filho, P.W.M., Guimarães, J.T.F., et al., 2015. Use of multiproxy approaches to determine the origin and depositional processes in modern lacustrine sediments: Carajás Plateau, Southeastern Amazon, Brazil. Appl. Geochem. $52,130-146$.

Sahoo, P.K., Guimarães, J.T.F., Souza-Filho, P.W.M., Silva, M.S., et al., 2016a. Geochemistry of upland lacustrine sediments from Serra dos Carajás, Southeastern Amazon, Brazil: Implication for catchment weathering, provenance, and sedimentary processes. J. South Am. Earth Sci. 72, 178-190.

Sahoo, P.K., Guimarães, J.T.F., Souza-Filho, P.W.M., Silva, M.S., Silva Junior, R.O., Pessim, G., Moraes, B.C., Pessoa, P.F.P., Rodrigues, T.M., Costa, M.F., Dall'Agnol, R., 2016b. Influence of seasonal variation on the hydro-biogeochemical characteristics of two upland lakes of the southeastern Amazon, Brazil. Anais da Academia Brasileira de Ciências 88, 2211-2227.

Sahoo, P.K., Guimarães, J.T.F., Souza-Filho, P.W.M., Silva, M.S., et al., 2017 a. Geochemical characterization of the largest upland lake of the Brazilian Amazonia: Impact of provenance and processes. J. South Am. Earth Sci. 80, 541-558. 
Sahoo, P.K., Guimarãees, J.T.F., Souza-filho, P.W.M., Bozelli, R.L., et al., 2017b. Limnological characteristics and planktonic diversity of five tropical upland lakes from Brazilian Amazon. Ann. Limnol-Int. J. Lim. 53, 467-483.

Sahoo, P.K., Guimarãees, J.T.F., Souza-filho, P.W.M., Powell, M.A., et al., 2019. Statistical analysis of lake sediment geochemical data for understanding surface geological factors and processes: An example from Amazonian upland lakes, Brazil. Catena 175, 47-62.

Schaefer, C.G.R.E., Lima Neto, E., Corrêa, G.R., Simas, F.N.B., Campos, J.F., De Mendonça, B.A.F., 2016. Geoenviroments, soils and carbon stocks at Serra Sul of Carajás, Para State, Brazil. Bol Mus Para Emílio Goeldi Cienc Nat 11(1), 85-101.

Seltzer, G., Rodbell, D., Burns, S., 2000. Isotopic evidence for late Quaternary climatic change in tropical South America. Geology 28, 35-38.

Schnurrenberger, D., Russell, J., Kerry, K., 2003. Classification of lacustrine sediments based on sedimentary components. J. Paleolimnol. 29, 141-154.

Sifeddine, A., Martin, L., Turcq, B., Ribeiro, C.V., Soubies, F., Cordeiro, R.C., Suguio, K., 2001. Variations of the Amazonian rainforest environment: a sedimentological record covering 30,000 years. Palaeogeogr. Palaeoclimatol. Palaeoecol. 168, 221-235.

Silva, M.S., Guimarães, J.T.F., Souza Filho, P.W.M., Nascimento Júnior, W.R., Sahoo, P.K., Costa, F.R., Silva Júnior, R.O., Rodrigues, T.M., Costa, M.F., 2018. Morphology and morphometry of upland lakes over lateritic crust, Serra dos Carajás, southeastern Amazon region. Anais da Academia Brasileira de Ciências 90(2), 13091325.

Silva Júnior, R.O., Souza, E.B.D., Tavares, A.L., Mota, J.A., Ferreira, D.B.S., SouzaFilho, P.W.M., Rocha, E.J.P.D. 2017. Three decades of reference evapotranspiration estimates for a tropical watershed in the eastern Amazon. Anais da Academia Brasileira de Ciências 89(3), 1985-2002.

Skirycz, A., Castilho, A., Chaparro, C., Carvalho, N., Tzotzos, G., Siqueira, J.O., 2014. Canga biodiversity, a matter of mining. Front. Plant Sci. 5, 1-9.

SMEWW. 2005. 1060-Collection and preservation of samples. Standard Methods for the Examination of Water and Wastewater.

Smith, C.B., Cohen, M.C.L., Pessenda, L.C.R., França, M.C., Guimarães, J.T.F., 2012. Holocenic proxies of sedimentary organic matter and the evolution of Lake ArariAmazon Region. Catena 90, 26-38.

Smith, R.J., Mayle, F.E., 2017. Impact of mid- to late Holocene precipitation changes on vegetation across lowland tropical South America: a paleo-data synthesis. Quaternary Research 89, 134-155.

Soubies, F., Suguio, K, Martin, L. et al., 1991. The Quaternary lacustrine deposits of the Serra dos Carajás (state of Pará, Brazil): ages and other preliminary results Boletim IG-USP. Publicação Especial 8, 223-243.

Souza-Filho, P.W.M., Guimarães, J.T.F., Silva, M.S., Costa, F.R., Sahoo, P.K., Maurity, C.W., Dall'Agnol, R., 2016a. Basin morphology, sedimentology and seismic stratigraphy of an upland lake from Serra dos Carajás, southeastern Amazon, Brazil. Bol. Mus. Para. Emílio Goeldi. Cienc. Nat., 11(1), 71-83.

Souza, E.B., Ferreira, D.B.D.S., Guimarães, J.T.F., Franco, V.D.S., Azevedo, F.T.M.D., Moraes, B.C.D., Souza, P.J.D.O.P. 2017. Padrões climatológicos e tendências da precipitação nos regimes chuvoso e seco da Amazônia oriental. Revista Brasileira de Climatologia 21, 81-93.

Souza-Filho, P.W.M., Souza, E.B., Silva Júnior, R.O., Nascimento, W.R., Versiani de Mendonça, B.R., Guimarães, J.T.F., Dall'Agnol, R., Siqueira, J.O., 2016b. Four 
decades of land-cover, land-use and hydroclimatology changes in the Itacaiúnas River watershed, southeastern Amazon. Journal of Environmental Management 167, 175-184.

Tavares, A.L., Carmo, A.M.C., Silva Júnior, R.O., Souza-Filho, P.W.M., Silva, M.S., Ferreira, D.B.S., Nascimento Júnior, W.R., Dall'Agnol, R. 2018. Climate indicators for a watershed in the eastern amazon. Revista Brasileira de Climatologia 23, 389-410.

Thornton, S.F., McManus, J., 1994. Applications of organic carbon and nitrogen stable isotope and $\mathrm{C} / \mathrm{N}$ ratios as source indicators of organic matter provenance in estuarine systems: evidence from the Tay Estuary, Scotland. Estuar. Coast. Shelf Sci. $38,219-233$.

Tolbert, G.E., Tremaine, J.W., Melcher, G.C., et al. 1971. The recently discovered Serra dos Carajas iron deposits, northern Brazil. Economic Geology 66, 985-994.

Troxler, T.G., Richards, J.H., 2009. $\delta^{13} \mathrm{C}, \delta^{15} \mathrm{~N}$, carbon, nitrogen and phosphorus as indicators of plant ecophysiology and organic matter pathways in Everglads deep slough, Florida, USA. Aquat. Bot. 91, 157-165.

Vasconcelos, P.M., Becker, T.A., Renne, P.R., Brimhall, G.H., 1994. Direct dating of weathering phenomena by K-Ar and 40Ar/39Ar analysis of supergene-Mn oxides. Geochim. Cosmochim. Acta 58, 1635-1665.

Viana, P.L., Mota, N.F., Gil, A.S.B., et al., 2016. Flora of the cangas of the Serra dos Carajás, Pará, Brazil, history, study area and methodology. Rodriguésia 67(5), 11071124.

Viehberg, F. A., Ülgen, U. B., Damc, E., Franz, S. O., Ön, S. A., Roeser, P. A., Çaĝatay, M.N., Litt, T., Melles, M. 2012. Seasonal hydrochemical changes and spatial sedimentological variations in Lake Iznik (NW Turkey), Quaternary International 274, $102-111$.

Walker, R.G., 1992. Facies, facies models and modern stratigraphic concepts. In: Walker, R.G., James, N.P. (Eds.), Facies Models - Response to Sea Level Change, second ed. Geological Association of Canada, Ontario, pp. 1-14.

Wang, X., Edwards, L.R., Auler, A.S., Cheng, H., Kong, X., Wang, Y., Cruz, F.W., Dorale, J.A., Chiang, H.W., 2017. Hydroclimate changes across the Amazon lowlands over the past 45,000 years. Nature 514, 204-207.

Wennrich, V., Francke, A., Dehnert, A., Juschus, et al., 2013. Modern sedimentation patterns in Lake El'gygytgyn, NE Russia, derived from surface sediment and inlet streams samples. Clim. Past 9, 135-148.

Wetzel, R.G., 2001. Oxygen. In: Wetzel, R.G., (Ed.), Limnology. Academic Press, London, pp. 151-168.

Zhang, Y., Zhang, X., Chiessi, C., Mulitza, S., Zhang, X., Lohmann, G., Prange, M., Behling, H., Zabel, M., Govin, A., Sawakuchi, A.O., Cruz, F.W., Wefer, G., 2016. Equatorial Pacific forcing of western Amazonian precipitation during Heinrich Stadial 1. Scientific Reports 6, 35866. 